
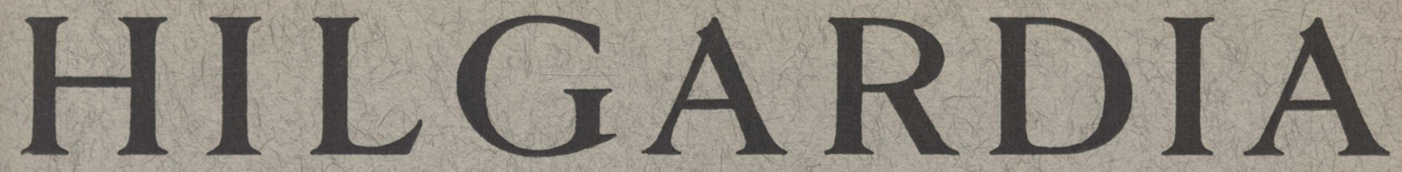

A Journal of Agricultural Science Published by the California Agricultural Experiment Station

\title{
REPORT ON DIAGNOSES OF DISEASED INSECTS 1944-1950
}

\author{
EDWARD A. STEINHAUS
}

This Issue Completes Volume 20 
This paper presents a general and summarized report on the diagnoses of 575 accessions of dead and diseased insects, plus 27 accessions of healthy insects examined for symbiofes, received at the Laboratory of Insect Pathology, Division of Biological Control, in Berkeley between August 1, 1944 and December 31, 1950.

Among the microorganisms observed in or isolated from the insects submitted for diagnosis were found several apparently new species of viruses, bacteria, fungi, protozoa, and symbiotes, some of which are reported here for the first time. Included in this report are the principal results obtained while conducting small research projects originating with some of the accessions. The findings include: observation of several new as well as several previously recognized virus infections, results of an attempt to grow insect viruses in embryonated hen's eggs, reisolation and redetermination of the bacterium responsible for widespread epizootics among grasshoppers, a revaluation of the pathogenic effects of so-called Bacillus " $\mathrm{C}$ " for scale insects, new host and locality data for several important entomogenous fungi and protozoa, and new and important records regarding certain intracellular and caecal symbiotes of insects.

See outside back cover for Table of Contents. 


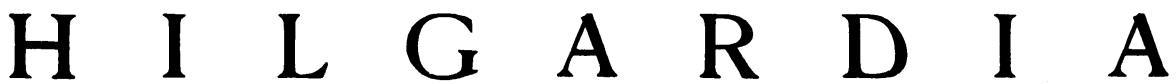

A Journal of Agricultural Science Published by

the California Agricultural Experiment Station

VoL. 20

MAY, 1951

No. 22

\section{REPORT ON DIAGNOSES OF DISEASED INSECTS 1944-1950'}

\author{
EDWARD A. STEINHAUS ${ }^{2}$
}

\section{INTRODUCTION}

For the Past several years the Laboratory of Insect Pathology in the Division of Biological Control on the Berkeley campus of the University of California has been receiving an increasing number of specimens of diseased insects from individuals and organizations requesting diagnoses. These specimens (subject to federal and state quarantine regulations) have been received from nearly all parts of the United States and from many foreign countries. In order to meet more efficiently the increasing demands of requests for the diagnosis of diseased insects, a diagnostic service was recently established (Steinhaus, $1950^{3}$ ) to meet the needs of biologists generally and in particular entomologists and agriculturists. Recommended shipping procedures and the general methods used in identifying the various diseases and their agents have been published elsewhere (Steinhaus, 1949a, p. 9-13; 1950), and may be had from our laboratory upon request.

A total of 575 accessions were received at an irregular and spasmodic rate from August 1, 1944 through December 31, 1950, at the end of which time the diagnostic service was formally instituted. Since it had not been originally anticipated that our laboratory would be called upon to perform such a diagnostic service, many of the early records of the period are incomplete and indefinite. Nevertheless, a great deal of valuable information relating to the microbial diseases of insects, as well as to data concerning a number of new microorganisms and new host records and to mutualistic symbiotes, were gathered and established during this time. Now, with the formal organization of the diagnostic service, it is thought desirable to "clear the books" so to speak, and to report briefly on some of the more pertinent diagnoses of accessions received during the years in which the procedures used in making the diagnoses were unorganized. This will serve in gathering together the

\footnotetext{
${ }^{1}$ Contribution from the Laboratory of Insect Pathology, Division of Biological Control, College of Agriculture, University of California, Berkeley 4, California. Submitted for publication February 21, 1951.

${ }^{2}$ Associate Professor of Insect Pathology and Associate Insect Pathologist in the Experiment Station, Berkeley.

${ }^{3}$ See "Literature Cited" for citations, referred to in text by author and date.
} 
loose ends and, it is hoped, provide for regular and more systematic reporting in the future if the publication of such reports appears to be justified.

For convenience, the following report is separated into four sections (virus infections, bacterial infections, fungous infections, and protozoan infections) according to the type of causative agent concerned. In addition there is a section dealing with accessions of healthy insects submitted to us for the purpose of determining the presence or absence of intracellular and caecal symbiotes. A host index will be found at the end of this report (p.674).

\section{VIRUS INFECTIONS}

Insects infected with or dead of virus infections and received by our laboratory have comprised approximately 18 per cent of the accessions received, and have fallen into three categories: polyhedroses (characterized by the presence of polyhedral inclusions), granuloses (characterized by the presence of granular inclusions), and those virus infections in which no inclusion body has been recognized. Some of the virus accessions have led to extended research projects; others have so far provided only the recording of their presence in the submitted host as herein reported.

\section{Polyhedroses}

Polyhedrosis in Alfalfa Caterpillar. On September 8, 1945, Ray F. Smith brought to the author several diseased specimens of the alfalfa caterpillar, Colias philodice eurytheme Boisduval, which were dying in large numbers in alfalfa fields in northern California. These particular specimens were collected in a field 11/4 miles east of Westley, California. Although Chapman and Glaser (1915) had suspected that the alfalfa caterpillar was susceptible to a "wilt disease," and Dean and Smith (1935) (the latter author having observed the disease in 1927 and 1928) in Kansas reported the infection as one caused by a polyhedral virus, the disease as it occurred in California had come to be generally regarded as one caused by a bacterium. On the basis of our 1945 and subsequent diagnoses the bacterial etiology was discounted and the presence of the polyhedrosis in California was definitely established (Steinhaus, 1945a). Later (Steinhaus, 1948, 1949b) the virus itself (Borrelina campeoles Steinhaus) was isolated and described, and was used in the first successful experimental attempts to control a field-crop pest through the dissemination of a virus (Steinhaus and Thompson, 1949a; Thompson and Steinhaus, 1950). Subsequent shipments from other parts of California as well as two from Maryland have also been diagnosed as being infected with the polyhedrosis. Attempts to cultivate this virus in tissues of the embryonated chick will be described a few pages hence.

Polyhedrosis in Western Hemlock Looper. In September, 1945, we received from R. L. Furniss 75 diseased specimens of the western hemlock looper, Lambdina fiscellaria lugubrosa (Hulst), collected in Pacific County, Washington. These specimens were those remaining from two lots of larvae held in rearing cages for a short time after having been collected. Of a total of 500 insects all had died of the infection except these 75 , which were in early to late stages of the disease. The diagnosis established that the disease was a polyhedrosis. 
Polyhedrosis in California Oakworm. In the course of investigating certain aspects of the biology of the California oakworm, Phryganidia californica Packard, W. S. Sibray noticed larvae of this insect dead and dying of what was apparently a disease. On December 18, 1945, two larvae originally collected as eggs in Strawberry Canyon on the University of California campus in Berkeley and reared in the laboratory were submitted to us for diagnosis. The symptomatology of the diseased larvae indicated a polyhedrosis infection. This was readily confirmed by the microscopic demonstration of polyhedra (fig. 1,B). Specimens submitted on subsequent dates have also been found to be suffering from this polyhedrosis. The virus itself, Borrelina peremptor Steinhaus, (fig. 1,A) has been isolated and described (Steinhaus, $1949 b$ ). The polyhedral inclusions characteristic of this disease had been seen by earlier workers (e.g., Chapman and Glaser, 1915).

Polyhedrosis in Yellow-Striped Armyworm. Several accessions of the western yellow-striped armyworm, Prodenia praefica Grote, have been diagnosed as being infected with a polyhedrosis virus (fig. $1, C, D$ ). The disease is common in yellow-striped armyworms in California, and has been recognized in western United States since at least 1932 (e.g., Blanchard and Conger, 1932). Our first positive diagnosis was made on a specimen submitted to the laboratory by Ray F. Smith on September 4, 1946, and collected by him four miles southeast of Tracy, California. This diagnosis was also obtained on subsequent accessions. The polyhedrosis virus itself (Borrelina olethria Steinhaus) was isolated and described in 1949 (Steinhaus, 1949b).

Polyhedrosis in Douglas-fir Tussock Moth Larvae. On June 27, 1947, a shipment of diseased larvae of the Douglas-fir tussock moth, Hemerocampa pseudotsugata McD., was received from R. L. Furniss who had collected the specimens near Troy, Oregon. A subsequent shipment was received on August 12, 1947, from the same locality. During the same month J. C. Evenden forwarded similarly diseased larvae from Colville, Washington, and Orofino, Idaho. All these shipments contained larvae suffering from polyhedralvirus infections. Both Furniss and Evenden considered the disease to be an important factor in the natural control of the insect. Mention of our diagnosis of the material from Evenden is included in the report by Evenden and Jost (1947) on tussock moth control in northern Idaho.

Polyhedrosis in Armyworm. Although the armyworm, Cirphis unipuncta (Haw.) [Leucania unipuncta (Haw.)], has been found to suffer from a polyhedrosis in parts of eastern United States and in such removed places as Rhodesia, it has not hitherto been reported in California. (Brief textbook reference to its presence in California was made by the author in 1949, but this concerns the same diagnosis referred to here.) On August 13, 1946, several diseased cutworms were received from G. T. Bottger of Anaheim, California, where they were being reared for toxicity tests. This accession was diagnosed as being infected with a polyhedrosis virus, and constitutes the first known finding of the disease in California. On March 11, 1949, N. F. Hardman sent us several dead and dying cutworms which had been a part of the colony maintained by the Agricultural Research Laboratory of the Stauffer Chemical Company at Mountain View, California for insecticide testing purposes. At the time the specimens were collected the colony was 


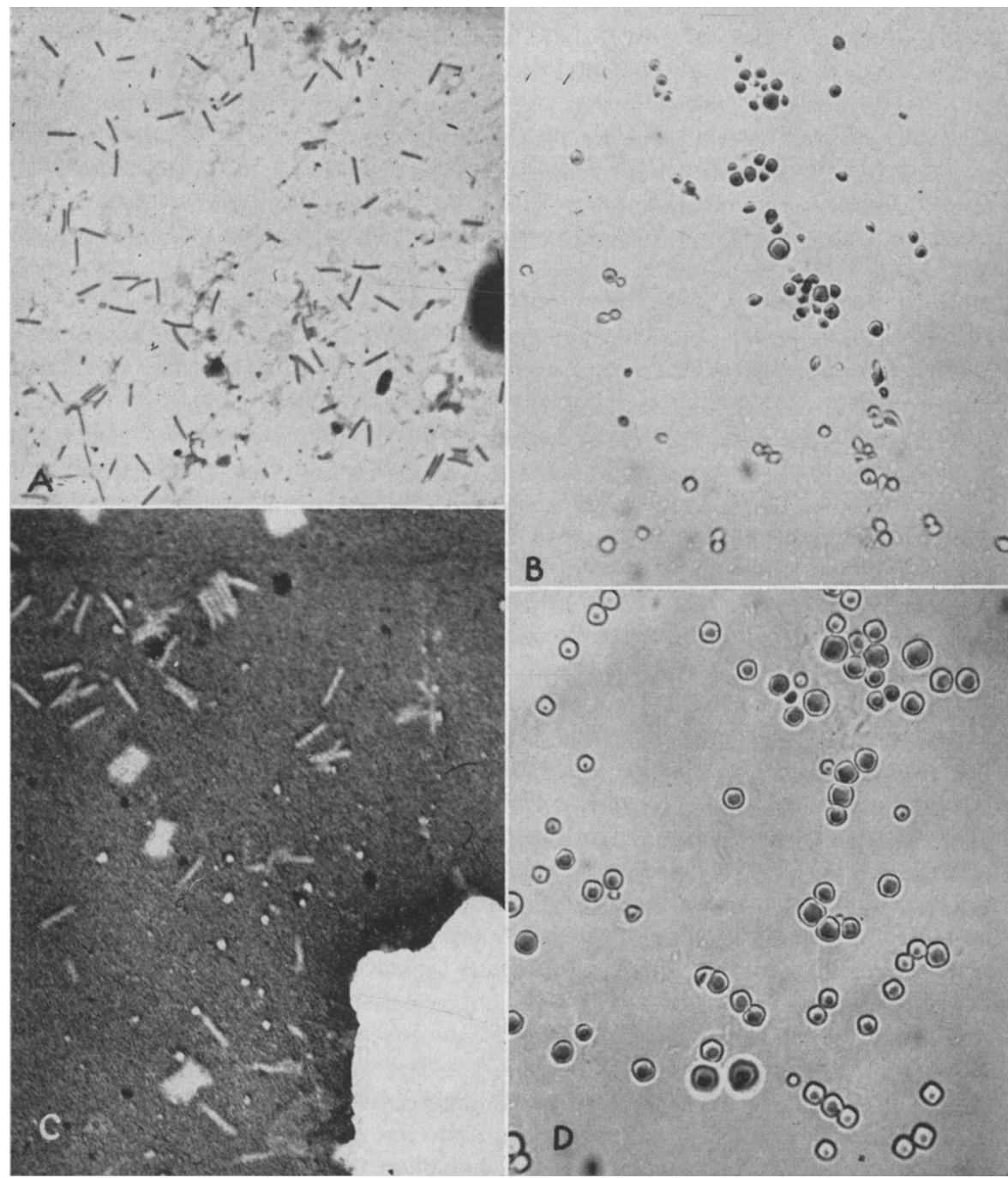

Fig. 1. Virus rods and polyhedra. A. Electron micrograph of Borrelina peremptor Sth., the virus causing a polyhedrosis in the California oakworm, Phryganidia californica Pack.; and $B$, the polyhedra found in oakworm larvae infected with the virus as seen in a light microscope preparation. $C$. Borrelina olethria Sth., the virus causing a polyhedrosis in the western yellow-striped armyworm, Prodenia praefica Grote; and $D$, the associated polyhedra as seen free in the hemolymph of the insect. Approximate magnifications $A, 11,850 \times$; $B, 920 \times ; C, 15,960 \times ; D, 920 \times$.

sustaining a mortality of about 15 per cent. All the affected larvae exhibited symptoms typical of a polyhedrosis and microseopic observations confirmed the diagnosis.

Polyhedrosis in Tent Caterpillars. That tent caterpillars are subject to polyhedroses has been known since the diseases were reported by Glaser and 
Chapman in 1913. What was in all probability a polyhedral infection in the eastern tent caterpillar, Malacosoma americanum (Fabr.), was seen earlier by Fiske in New Hampshire (Howard and Fiske, 1911). Reeks (1946) reported a "wilt disease" to be responsible for reducing the population of the forest tent caterpillar in the maritime provinces in Canada. On July 25, 1949, R. G. Rosensteil submitted to the laboratory specimens of the forest tent caterpillar, Malacosoma disstria Hbn., and the western tent caterpillar, Malacosoma pluviale (Dyar), collected along the coast in Oregon. Both species were infected with polyhedral viruses. The exact location of the collection of the latter species was 12 miles southeast of Seaside, Oregon. This virus, as well as that from the western tent caterpillar, was subsequently isolated and measured (Steinhaus, 1949b). To our knowledge this is the first record of a polyhedrosis in Malacosoma pluviale, although what may be the same disease in this insect has recently been reported from Canada (Bergold and McGugan, 1951). Specimens of $M$. pluviale collected in Whatcom and Mason counties, Washington, by E. P. Breakey and E. F. Dailey and received at our laboratory in July and August, 1950, were also found to have died of polyhedral disease. The areas from which these collections were made have shown evidence of having been the scene of extensive epizootics of the disease. On July 3, 1950, Harriette B. Wasser of our laboratory collected several diseased specimens of the great basin tent caterpillar, Malacosoma fragilis (Stretch), from near Dardanelle, California, in the Stanislaus National Forest. These also proved to be infected with a polyhedral virus and apparently provide the first record of its occurrence. Whether or not the viruses in these three tent caterpillars are the same, closely related, or distinct, remains to be determined.

Polyhedrosis in Beet Armyworm. Specimens of the beet armyworm, Laphygma exigua (Hbn.), brought into the laboratory sometime during the summer of 1946 were found to be infected with a polyhedrosis. Unfortunately, the receipt of these specimens was not recorded as an accession so their exact source is not known except that they were collected in beet fields in northern California. The first definite accession record having to do with a polyhedrosis in this insect is that of September 10, 1947, when 25 larvae were brought in by K. D. Snyder. They were collected near Westley, California. Of the 25 larvae, 8 showed the presence of polyhedra when their tissues were examined microscopically. Later (Steinhaus, 1949b) the virus itself (fig. 2) was isolated and measured.

Polyhedrosis in Red-Headed Pine Sawfly. On December 27, 1949, we received from L. A. Hetrick several dead larvae of the red-headed pine sawfly, Neodiprion lecontei (Fitch), collected near Gainesville, Florida. A diagnosis of polyhedrosis was made. The bodies of the dead insects contained large numbers of polyhedra. To our knowledge this is the first report of a virus disease of this type in this insect. It is Hetrick's opinion that a disease he described earlier (1941) in the larva of another sawfly, Neodiprion americanum (Leach), is also caused by a polyhedral virus.

Possible Polyhedral Infections. Two accessions were received which, although the diagnosis could not be definitely established, might possibly represent instances of polyhedral infection. The first of these were nine 
chrysalises of the pandora moth, Coloradia pandora Blake. The specimens were collected in the Little Kern River drainage basin by George Struble on September 9, 1947. At the time of collection they were shriveled and dry. The material reached our laboratory on October 30, 1947. Examination of this dried material indicated that a polyhedrosis might have been responsible for the death of the insects, but a definite diagnosis to this effect could not be recorded. The second accession referred to concerned four larvae of the

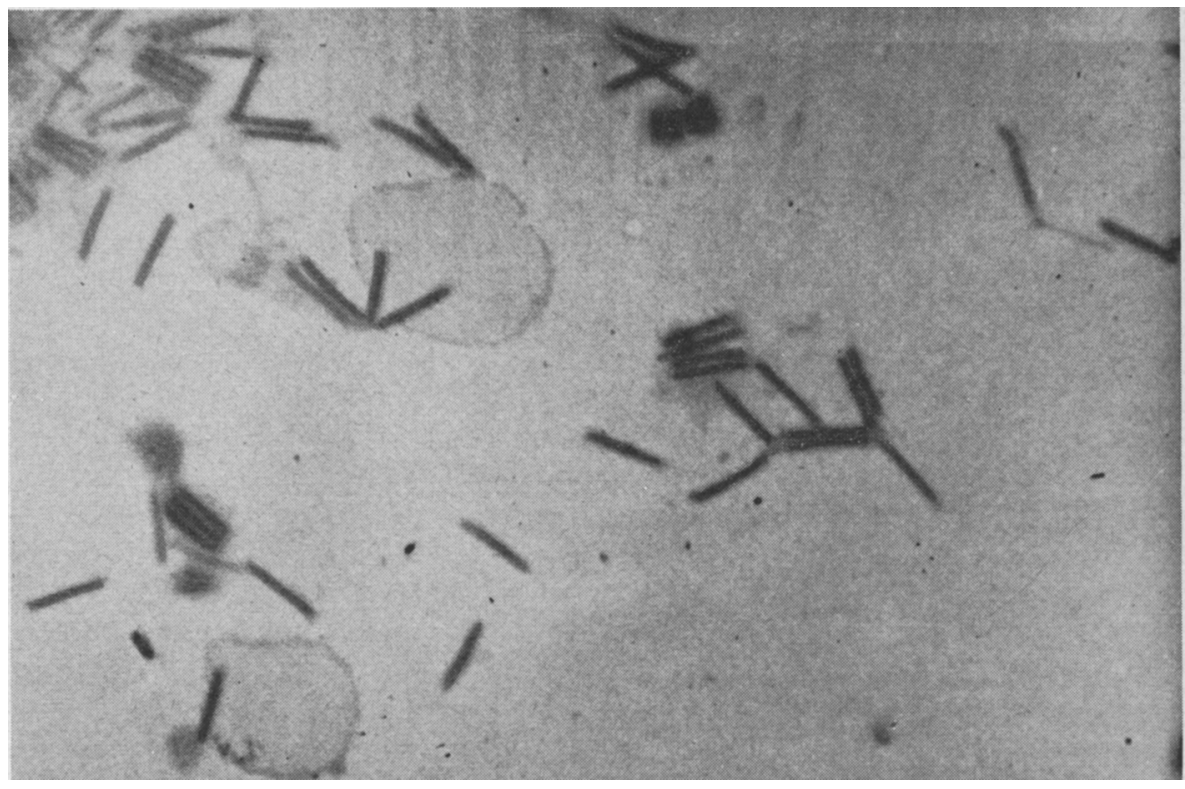

Fig. 2. Virus rods responsible for a polyhedrosis of the beet armyworm, Laphygma exigua (Hbn.). Magnification approximately $31,850 \times$.

painted-lady, Vanessa cardui (Linn.), collected on May 25, 1949 near Palo Alto by Robert Beers. Inclusions very similar to polyhedra were observed in these specimens, but confirmation by chemical and optical tests as well as by the electron microscope was not obtained.

\section{Granuloses}

Granuloses in Variegated Cutworm and Red-banded Leaf Roller. During the past few years five different granuloses have been discovered in California insects by members of our laboratory staff. In addition, one granulosis has been found in larvae of the red-banded leaf roller [Argyrotaenia velutinana (Wlkr.)] submitted for diagnosis from Blacksburg, Virginia. The five Californian insects are: the variegated cutworm, Peridroma margaritosa (Haw.), the buckeye caterpillar, Junonia coenia Hbn., the salt-marsh caterpillar, Estigmene acraea (Drury), the omnivorous looper, Sabulodes caberata Guenée, and the imported cabbageworm, Pieris rapae (Linn.). Since at the time these infections were discovered it was not our usual practice to accession 
material collected by our own staff members, only the variegated cutworm material and the larvae from Virginia were handled according to the routine diagnostic procedures.

The infected cutworms were sent to us by F. H. Wymore in February, 1947, from Anaheim, California, where they were being reared by the Union Oil Company for insecticide testing. They were diagnosed as suffering from a virus infection which we tentatively called a "granulosis," recognizing its similarity to a disease described in 1934 by Paillot in another cutworm, Euxoa segetum Schiff., in France. The variegated cutworm infection was the first of its kind to be reported outside of France. After considerable study, the virus itself was isolated and described (Steinhaus, 1947b; Steinhaus, Hughes, and Wasser, 1949 ; Steinhaus, 1949a, $b$ ) (fig. $3 A, B$ ).

The diseased larvae of the red-banded leaf roller were received from W. J. Schoene, Blackburg, Virginia, on December 5, 1949. Subsequent shipments from the same general locality were received from Nannie V. Sibold. These specimens proved to be the first instance of a granulosis found in the United States outside of California. Details of our diagnosis have been published elsewhere (Sibold, 1950; Schoene and Sibold, 1951; Wasser and Steinhaus, 1951).

\section{Cultivation Attempts}

At this point it may be noted that an attempt was made to cultivate certain of the viruses mentioned in the preceding accession descriptions, in the tissues and fluids of the embryonated chick. This effort was made in cooperation with Lyndahl E. Hughes and C. B. Philip of the Rocky Mountain Laboratory, U. S. Public Health Service, Hamilton, Montana. Between March 7 and May 12, 1950, six different viruses, crude and purified, were sent to Hughes in Hamilton for inoculation into fertile eggs; these were the polyhedrosis viruses of the alfalfa caterpillar, the beet armyworm, the California oakworm, and the silkworm, and the granulosis viruses of the variegated eutworm and the buckeye caterpillar. Most of the cultivation attempts were made with alfalfa caterpillar and beet armyworm viruses. After the viruses had been inoculated into or passed through fertile eggs and properly incubated, material from the eggs or the eggs themselves were sent by airmail to Berkeley where biological and microscopical tests for the presence of virus were made in our laboratory. The author was assisted in this part of the investigation by Kenneth M. Hughes who prepared the purifications and the electron micrographs.

The results obtained in this study were perplexing and inconclusive. For example, both the alfalfa caterpillar and the beet armyworm virus preparations caused the death of the embryos in 5 to 9 days. This killing effect manifested itself through several egg passages, at least seven, and could be titrated out to $10^{-6}$. In spite of such consistently positive results as these the original viruses could not be demonstrated in any of the tissues or fluids of the killed embryos. Regardless of how soon after death the embryonic materials were tested, they showed no infectivity whatever for the appropriate host insect when fed to or inoculated into these animals. No polyhedral inclusions could be found in the material, and electron micrographs showed no evidence of the virus itself in any of the fractions and purifications prepared 

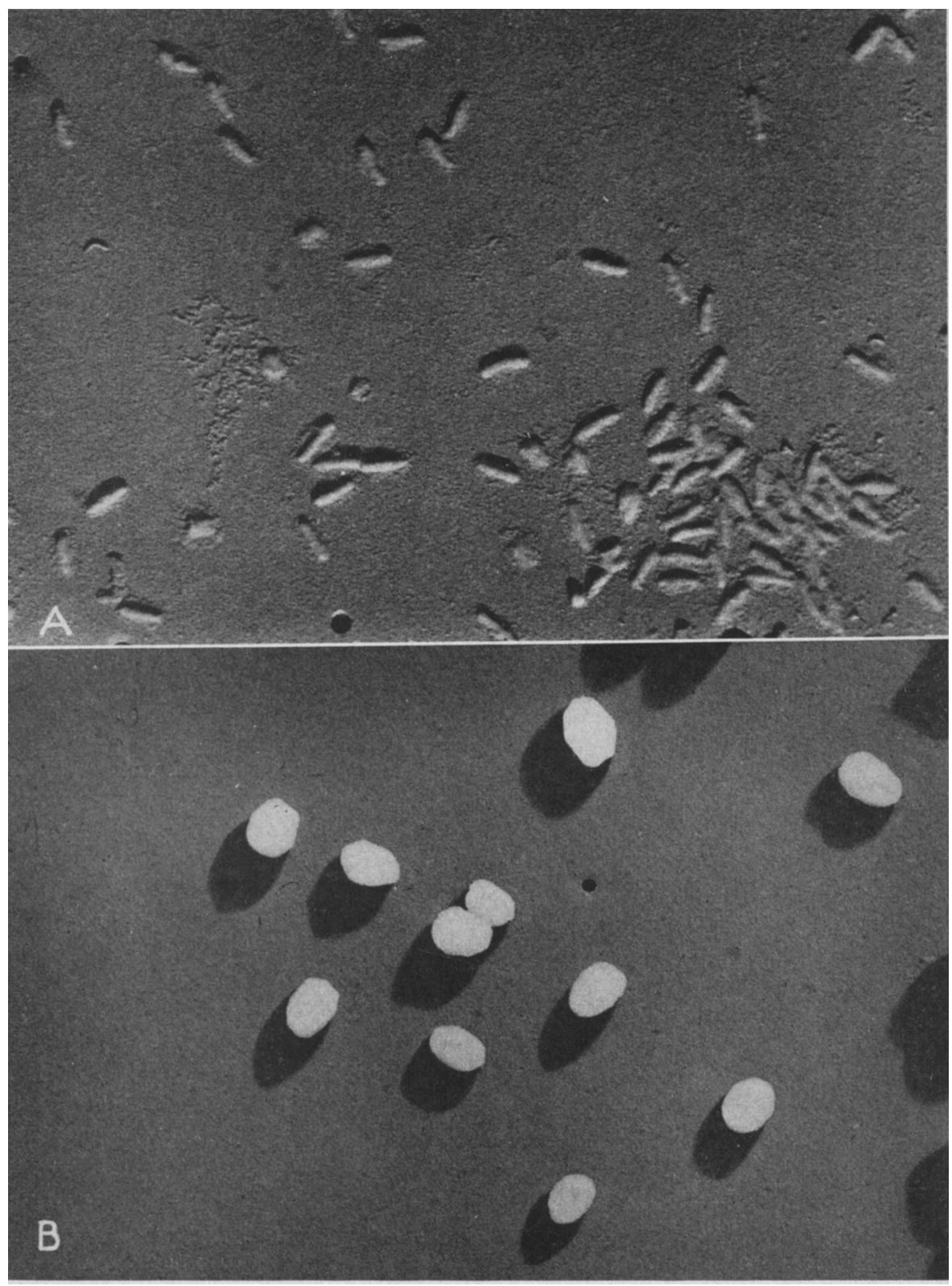

Fig. 3. Electron micrographs of the virus particles $(A)$ and granular inclusions $(B)$ (both palladium shadowed) characteristic of the granulosis of the variegated cutworm, Peridroma margaritosa (Haw.). Magnification approximately $17,700 \times$. 
from triturated embryo material. Nothing of significance was revealed using ordinary microscopy as well as darkfield and phase microscopy. There is probably a faint possibility that egg passage so modified the virus that it was no longer virulent for its natural host, but this would not explain the apparent absence of the agent in electron micrograph preparations. Therefore, despite the fact that preparations from virus-diseased insects appeared to be responsible for the death of inoculated chick embryos in well controlled experiments there was no conclusive evidence that this lethal effect resulted from the activity of the recognized insect virus or that such virus had propagated itself in any of the embryonic fluids or tissues. Further investigation of this matter is required before a logical explanation of these results can be made.

In this connection, L. E. Hughes in Hamilton has attempted to grow the virus of silkworm jaundice by the Zinsser culture method of growing certain rickettsiae, using crushed normal eggs of the Rocky Mountain wood tick, Dermacentor andersoni Stiles, as an overlay. Although these cultures were carried through three blind transfers at ten-day intervals only negative results were obtained.

\section{Noninclusion Virus Infections}

Although in no case has the virus as yet been demonstrated with certainty by means of the electron microseope, the laboratory has received three sets of accessions in which the insects were apparently infected with noninclusion viruses-i.e., viruses not characterized by the formation of cellular inclusions demonstrable with a light microscope.

During 1948 and 1949 shipments of diseased honey bee (Apis mellifera Linn.) larvae were received from C. J. Burgin, R. K. Ashby, and V. H. Benson in Texas, C. E. Burnside in Wyoming, J. A. Munro in North Dakota, and J. E. Eckert in California. All shipments exhibited symptoms typical of sacbrood. Since the virus responsible for this infection has not been demonstrated by means of the electron microscope an effort to do so was made. Although small, spherical to slightly oval particles approximately 60 millimicrons in diameter were found in electron micrographs of the diseased material, there is no direct evidence that these represent the virus of sacbrood.

On April 18, 1950, J. E. Eckert, Davis, California, forwarded to us a number of adult honey bees which appeared to be victims of a virus-caused paralysis. The virus etiology of the disease has been claimed by Burnside (1945). Routine electron micrographs of the material we received failed to show anything that could be considered a virus. A more detailed study, however, might very well reveal the presence of such an agent.

On December 7, 1949, G. T. Bottger, U.S.D.A. Entomologist at Anaheim, California wrote that their laboratory colony of the armyworm, Cirphis unipuncta (Haw.) [Leucania unipuncta (Haw.)] was suffering from an infection having symptoms quite different from those characteristic of a polyhedrosis in the same insect. The new disease appeared only in the late larval instars, usually at about the time of maturity. The cuticula of the diseased larvae had a waxy appearance, and in some cases the midportion was somewhat enlarged. The liquefaction and disintegration characteristic of the 
polyhedrosis was not present in this disease. The greatest percentage of mortality occurred in the pupal stage when mortalities of 90 to 100 per cent were common.

Examination of two shipments of diseased cutworms failed to reveal any specimens infected with any recognizable microorganism. Neither polyhedral nor granular inclusions were present. Nevertheless the larvae were obviously diseased. Healthy cutworms fed food contaminated with material from dead or dying larvae became infected and showed symptoms typical of the disease. Filtrates of infectious material passed through bacteriological filters also proved infectious. This property together with the fact that no recognizable microorganisms or inclusion bodies were present in light microscope preparations indicates that the infectious agent may be of the nature of a filterable virus. Preliminary examination of infectious material with the electron microscope has so far not revealed anything which might be virus particles. Studies on the disease and its causative agent are still in progress, however, and it is hoped that our techniques may be so modified as to demonstrate the etiological agent with certainty.

\section{BACTERIAL INFECTIONS}

Although only a relatively small number of bacteria are known to be truly entomogenous and pathogenic only for insects, there are many other bacteria that are capable of causing infection in insects provided the appropriate conditions exist. Sometimes these bacteria are well-known species, at other times they turn out to be bacteria of rather nondeseript types or organisms which do not correspond to published descriptions of known species. Limitations of time and personnel have so far prevented us from making a thorough study of this latter group and from providing any more informative diagnosis than that of reporting the presence of bacteria in the diseased specimens. Twentyseven of our accessions were of this indefinite category and in most of these cases the diagnostic report was simply to the effect that the diseased material showed bacteria to be present. On the other hand, several accessions having to do with bacterial infections provided diagnoses of particular interest and importance. These together with some accessions that initiated significant small projects or studies are reported here. In all, insects in which bacteria were the only apparent cause of disease constituted approximately 20 per cent of the accessions.

\section{Enterobacteriaceae Infections}

Between August 30, 1944 and August 2, 1945, a large number of larvae of the potato tuberworm, Gnorimoschema operculella (Zeller), were examined to determine the cause of their death in an insectary at Albany, California. The tuberworm was being used as a host for the production of large numbers of the hymenopterous parasite Macrocentrus ancylivorus Roh., which was being distributed in California to aid in the control of the oriental fruit moth, Grapholitha molesta (Busck.). The diseased tuberworm larvae were submitted by Blair Bartlett, Charles Martin, and Glenn Finney. The insects were found to be dying of one or another of three bacterial diseases. One disease was caused by the red-pigmented bacterium Serratia marcescens Bizio; 
the other two infections by two coliform bacteria, one of which appeared to be Aerobacter cloacae (Jordan), the other a slow lactose fermenter, probably a Paracolobactrum. A more detailed report of these findings was published in 1945 (Steinhaus, 1945b).

Inasmuch as the literaure contains a considerable number of references to insect diseases caused by Serratia marcescens, it is not surprising that our laboratory should have received a number of accessions involving this redpigmented bacteria. In addition to the potato tuberworm, Serratia marcescens has been determined as the pathogen in diseased insects sent to our laboratory in the following instances: Macrocentrus ancylivorus Roh. and Dibrachys cavus Wlkr. reared on infected tuberworms ; pupae of mourning cloak butterfly, Nymphalis antiopa (Linn.) ; adult houseflies, Musca domestica Linn.; the termite Zootermopsis angusticollis (Hagen), all from Berkeley, California, and vicinity; and insectary-reared oriental fruit flies, Dacus dorsalis Hendel from Honolulu, Hawaii.

Coliform Infections in Grasshoppers. Although one of the most publicized diseases of an insect is the dysentery and septicemia in grasshoppers caused by so-called Coccobacillus acridiorum d'Herelle, its isolation from grasshoppers during epizootics in the United States has not been reported, excepting mention of the present study in a recent textbook (Steinhaus, 1949a). In spite of d'Herelle's claims of success in controlling grasshoppers in Mexico, Argentina, and Tunisia by the introduction and artificial distribution of the bacterium, conflicting results have been reported by other investigators attempting the same objective. Among the several explanations given for this general lack of success is that naturally occurring avirulent strains of the bacterium, morphologically and physiologically identical to d'Herelle's, as well as the presence of closely related bacteria, conferred an immunity on the insects and protected them from attack by the virulent, bona fide, "Coccobacillus acridiorum." Considerable confusion soon prevailed as to the exact role and significance of d'Herelle's organism in the dysenteric and septicemic conditions occurring in grasshoppers in various parts of the world. The true identity of "Coccobacillus acridiorum" also became confused, and its validity as a distinct species was questioned.

During the late summer and fall of 1945 and 1946, outbreaks of dysentery occurred in populations of the differential grasshopper, Melanoplus differentialis (Thos.), infesting fields of alfalfa in several areas of northern California. These outbreaks furnished an opportunity to determine if the organism represented by d'Herelle's "Coccobacillus acridiorum" were present in grasshoppers in California and, if present, to determine its true identity. The study was actually initiated, however, by an accession received from Ray F. Smith who on September 8, 1945, brought to our laboratory several dead and dying specimens of the differential grasshopper collected two miles east of Tracy, California. From these specimens as well as others collected by Smith and ourselves on subsequent dates in 1945 and in the fall of 1946, cultures of a characteristic gram-negative rodshaped bacterium were repeatedly isolated. Inoculation and feeding experiments confirmed the pathogenicity of this bacterium for their host, except that susceptibility to infectious feedings was variable. 
During the Tracy epizootic, routine bacteriological examinations were made of diseased insects submitted to us and collected by us from the field, and the cultures thus obtained were held on nutrient-agar slants until differential tests could be run on them. One typical and representative strain was retained from the 1945 examinations, and eight strains were retained from the 1946 examinations of diseased Melanoplus differentialis. In 1946, seven additional strains were isolated from apparently healthy grasshoppers of the same species.

Concurrent with these studies on Melanoplus, similar examinations were made of a species of Schistocerca [apparently Schistocerca shoshone (Thos.)] collected from the same area. Of the cultures isolated, one bacterial strain from a diseased specimen and four strains from apparently healthy specimens were retained for further study.

Each of the strains retained were studied with regard to their morphological, physiological, and cultural characteristics. Cultures of most of these strains were sent to C. A. Stuart, at Brown University, who generously examined them in similar fashion, and in addition made a few serological determinations. In general, Dr. Stuart's findings were essentially the same as those obtained in our laboratory. The cultures selected as representative of the bacterial flora of the diseased as well as the healthy grasshoppers were found to belong to either the coliform or the paracolon group of bacteria.

In order to compare the strains of bacteria isolated from the California epizootics with strains considered by earlier workers to be typical "Coccobacillus acridiorum," a request for cultures was dispatched to all laboratories and centers known to have been concerned at one time or another with the dissemination of the bacterium for purposes of grasshopper control. Only one source was able to supply us with transfers of the original d'Herelle cultures-the National Collection of Type Cultures, Lister Institute, Elstree, Herts. From this institution, three strains were obtained together with the following notations :

Strain-No. 1804-Isolated from diseased locusts by d'Herelle, and deposited in the Collection in 1924.

Strain No. 2162-Obtained from d'Herelle in 1925. No other details.

Strain No. 2163-Obtained from G. F. White, Bureau of Entomology, Washington, D.C. Original from d'Herelle.

Cultural and biochemical reactions of these three strains were tested by the same method that had been used with the California cultures. All three strains were gram-negative small rods (fig. 4) which fermented lactose with the production of acid and gas, and hence may be considered as belonging to the coliform group of bacteria.

On the basis of these studies of freshly isolated cultures, as well as of the original d'Herelle cultures obtained from the Lister Institute, and the critical examination and analyses of published data, the author became convinced that the so-called "Coccobacillus acridiorum" of d'Herelle is in fact a coliform or possibly a paracolon bacterium. Analyses of the cultural and biochemical data accumulated in this study indicate that it is similar to Aerobacter aerogenes (Kruse) and very likely a variety of this species or the closely related 
Aerobacter cloacae (Jordan). However, since some strains ferment lactose rather slowly, it is possible that the bacterium may be related to Paracolobactrum aerogenoides $\mathrm{B} ., \mathrm{S} .$, \& W. In any case, since Coccobacillus is not recognized as a valid genus, and since "Coccobacillus acridiorum" is apparently not in itself a distinct species, it would appear that a more logical, if temporary, designation of the organism would be that of a recognized coliform. Accordingly, in 1949 the combination Aerobacter aerogenes var. acri-

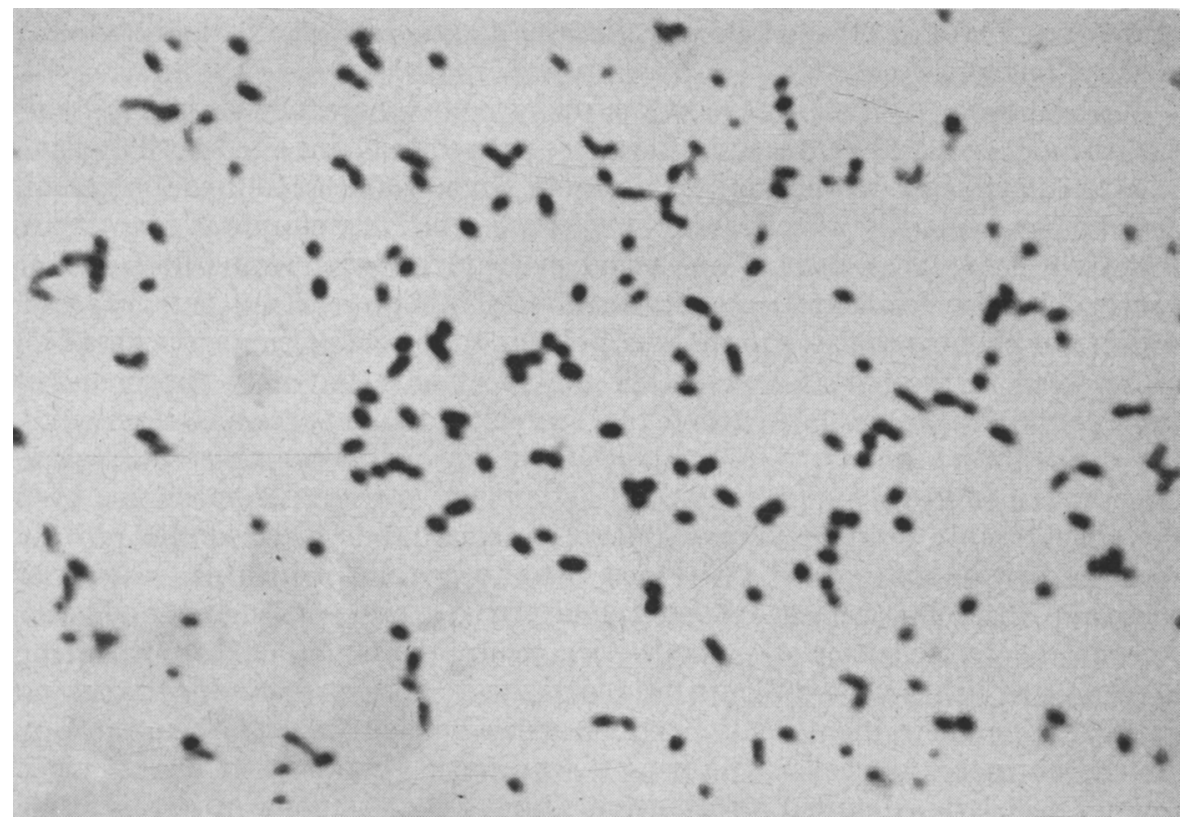

Fig. 4. Photomicrograph of Aerobacter aerogenes var. acridiorum (d'Herelle) (=Coccobacillus acridiorum d'Herelle), the cause of the bacterial dysentery in grasshoppers discussed in text. Magnification approximately $2730 \times$.

diorum (d'Herelle) was suggested by the author (Steinhaus, 1949a) in the course of a general discussion of the bacterium and the disease for which it is responsible.

Of particular interest is the fact that what appears to be the same organism, although probably in fewer numbers, occurs in Melanoplus that are apparently normal and healthy. The same situation possibly prevails in the Schistocerca species but enough data on this point have not been accumulated. It is noteworthy that the intestinal tracts of a considerable number of normal Schistocerca were bacteria-free; such was not found to be the case with Melanoplus.

Subsequent to most of the observations described in the preceding paragraphs, we received a number of diseased two-striped grasshoppers, Melanoplus bivittatus (Say), from Montana and North Dakota, and in both instances the mortality appeared to be the result of infection by Aerobacter aerogenes 
var. acridiorum. ${ }^{4}$ A culture of the bacterium was isolated from the Montana insects, but the North Dakota material was so old that the diagnosis was made from post mortem appearance alone. The Montana specimens were received on October 15, 1948, from G. T. York and on March 3, 1950, from J. R. Parker. The North Dakota grasshoppers were sent in by J. A. Munro on December 3,1949 . In both states the disease apparently was responsible for widespread epizootics in the course of which, in North Dakota, approximately 95 per cent of the grasshoppers were killed by the disease. Of additional interest is the fact that in North Dakota at the same time Melanoplus bivittatus (Say) was being destroyed by the disease, Melanoplus mexicanus (Sauss.) was not harmed by it.

With noteworthy frequency insects sent to our laboratory and found suffering from or killed by a bacterial disease proved to be infected with a gramnegative small rod of one kind or another. Since those gram-negative small rods known generally as coliform bacteria are relatively simple to identify as to group, it has been part of our usual procedure to determine first, on the basis of lactose fermentation and other tests, whether or not the organism concerned belongs to this group. If it belongs to the coliform group, this fact is reported to the person submitting the specimens, but only rarely has it been found expedient to identify the bacterium as to species. Occasionally the genus [Escherichia, Aerobacter, Klebsiella, or Paracolobactrum (slowlactose-fermenters)] is determined. Particularly interesting to us has been the considerable number of gram-negative small rods isolated that do not ferment lactose and which, therefore, usually are not coliforms. Not all of these are Enterobacteriaceae. Some belong to the families Pseudomonadaceae, Achromobacteriaceae, or other taxa. As a group, these nonlactose-fermenting bacteria are either very difficult to identify as to species or require time and facilities for their identification which exceed what we have been able to afford routinely. Moreover, the person sending in the diseased insects often did not desire this detailed information. During the past year or so this situation has changed somewhat and we have been endeavoring to identify at least to genus, and when possible, to species all bacteria isolated from insects and considered by us as a possible cause of the insect's death.

Other Coliform Infections. During the time we have been making routine diagnoses of diseased material sent to us for this purpose at least 25 strains of coliform bacteria have been isolated. In most instances death of the insect could be ascribed to no microbial cause other than the coliform; it seems likely, however, that in some cases the bacteria were secondary invaders to amicrobial influences. Coliform or paracolon bacteria have been isolated from the following dead or diseased insects, all submitted from points in California except as indicated: grubs of Pleocoma hirticollis vandykei Linsley from

\footnotetext{
${ }^{4}$ On March 12 and 26, 1951 (dates subsequent to those included in this report), specimens of Melanoplus bivittatus (Say), M. mexicanus (Sauss.), and M. dawsoni (Scudder) were received from J. R. Parker who found them diseased and dead in rearing eages in his Montana laboratory. Microscopic examination showed most of the specimens to be infected concurrently with what appeared to be the amoeba Malameba locustae (King and Taylor), and a microsporidian that is probably a new species of Nosema. Cysts of the amoeba were found primarily in the malpighian tubes while the spores of the microsporidian were found primarily in the fat tissue.
} 
near Livermore; the celery leaf tier, Phlyctaenia rubigalis (Guen.), and the armyworm, Cirphis unipuncta (Haw.), from Anaheim ; the alfalfa caterpillar, Colias philodice eurytheme Bdvl., from near Tracy, and from laboratory colonies; the western yellow-striped armyworm, Prodenia praefica Grote from alfalfa fields near Vernalis; the beet armyworm, Laphygma exigua (Hbn.), collected near Westley; the tobacco hornworm, Protoparce sexta (Johan.), from a colony being reared at Albany; the variegated cutworm, Peridroma margaritosa (Haw.), from Anaheim (in this case, the coliform was known to be secondary to a generalized granulosis virus infection); the tent caterpillar, Malacosoma constricta (Stretch), from a laboratory colony in Berkeley ; the western tent caterpillar, Malacosoma pluviale (Dyar), from near Lynden, Washington ; larvae of the green dock beetle, Gastroidea cyanea Melsh., Berkeley; the European corn borer, Pyrausta nubilalis (Hbn.), from points in Connecticut and Iowa; adults of the bordered plant bug, Euryophthalmus convivus (Stål), from near Tracy (the coliform isolated on this occasion probably represents part of the insect's normal flora and may, in fact, be the caecal symbiote in this insect); larvae of a brown lacewing, Hemerobius sp., collected in Berkeley; larvae of the yellow mealworm, Tenebrio molitor Linn., from a laboratory colony in Berkeley; and the potato tuberworm, Gnorimoschema operculella (Zeller), from insectaries in Berkeley, California, and Palisade, Colorado.

Noncoliform Infections. Gram-negative small rods which did not ferment lactose within 30 days and which for this and other reasons could not be considered as coliform or paracolon bacteria have been isolated from at least 12 species of diseased insects sent to us for diagnosis. A few of these were identified as to genus, others remain unidentifed. Several strains of Pseudomonas were recovered from diseased larvae of the European corn borer, Pyrausta nubilalis (Hbn.), from Iowa. A Flavobacterium was isolated from dead larvae of the celery leaf tier, Phlyctaenia rubigalis (Guen.), from an insectary at Anaheim, California.

Other gram-negative noncoliforms were isolated from larvae of the alfalfa weevil, Hypera postica (Gyll.); the armyworm, Cirphis unipuncta (Haw.) ; the alfalfa looper, Autographa californica (Speyer); the western yellowstriped armyworm, Prodenia praefica Grote; the alfalfa caterpillar, Colias philodice eurytheme Boisduval, the potato tuberworm, Gnorimoschema operculella (Zeller); grubs of Pleocoma hirticollis vandykei Linsley; the variegated cutworm, Peridroma margaritosa (Haw.) (the bacterium in this case was apparently a secondary invader to a granulosis virus); the beet armyworm, Laphygma exigua (Hbn.); and larvae of the green dock beetle, Gastroidea cyanea Melsh.; all from localities in California and most of them from points near Berkeley, California.

\section{Bacillaceae Infections}

Bacillus cereus and B. thuringiensis. In February and March, 1945, a culture of Indian-meal moth, Plodia interpunctella (Hbn.), being maintained in the Division of Entomology and Parasitology on the Berkeley campus of the University of California, was observed to have become infected and all but destroyed. Specimens of dead and diseased insects submitted by Ray F. 
Smith for diagnosis all yielded a gram-positive sporeforming rod similar to Bacillus cereus Fr. \& Fr. A culture of the bacillus was forwarded to Nathan R. Smith, a specialist of the genus Bacillus, who confirmed the identification. Later, in March 1949, another strain of Bacillus cereus was isolated from diseased larvae of Aphomia gularis (Zeller) found in an almond-shell bin in Oakland, California. Upon receipt of this bacillus, Smith recognized it also as a strain of Bacillus cereus. Both of these strains were very similar to a strain of Bacillus thuringiensis Berliner obtained by us in 1942 from Smith

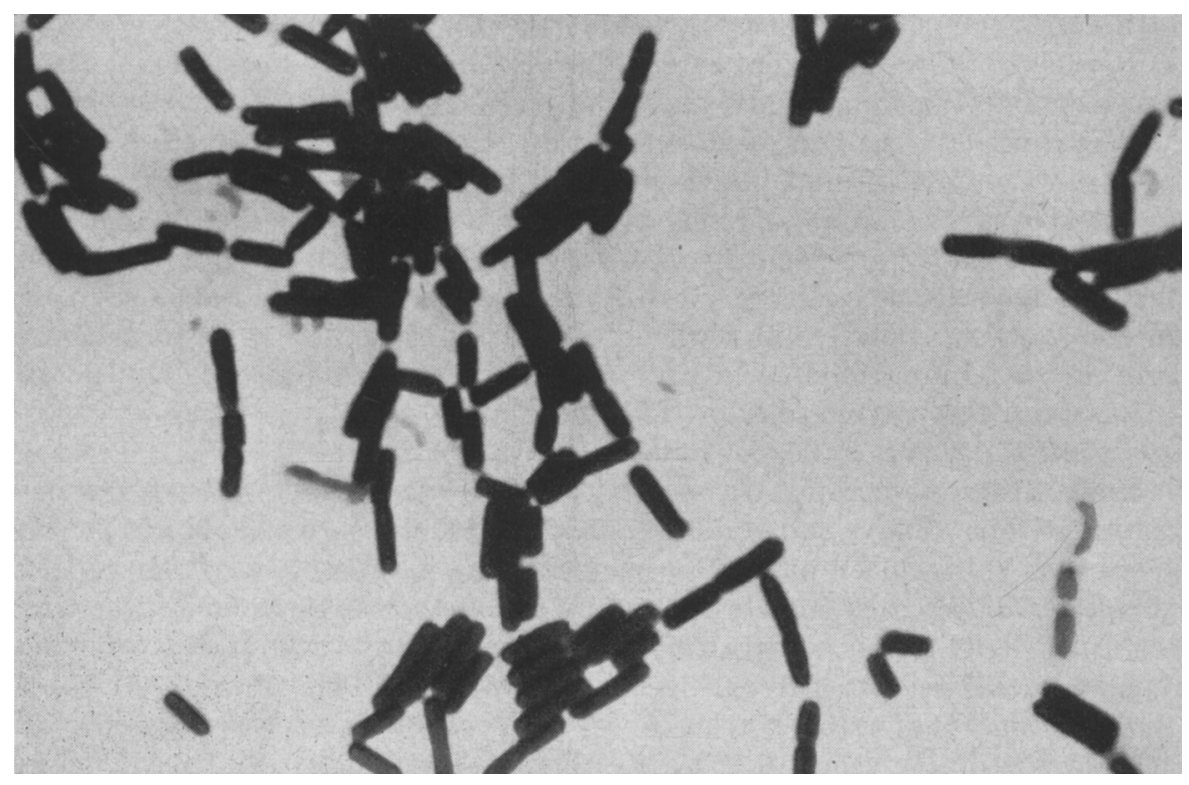

Fig. 5. Bacillus thuringiensis Berliner from a 20-hour culture on nutrient agar. Stained with Giemsa's solution. Magnification approximately $2135 \times$.

who had received it from J. R. Porter in 1940. Porter had secured it in 1936 from Otto Mattes who isolated it in Germany from diseased larvae of the Mediterranean flour moth, Ephestia kühniella Zeller, as did Berliner (1915) when he isolated it from the same source in 1911.

In the course of a study on the possible use of Bacillus thuringiensis (fig. 5 ) in the biological control of the alfalfa caterpillar (Steinhaus, 1951) the author observed that the three strains (from Plodia, Aphomia, and Ephestia) of Bacillus cereus concerned here were distinctly pathogenic for insects whereas strains of $B$. cereus from noninsect sources did not exhibit this pathogenicity. Upon reexamining the three strains from a morphological standpoint, Smith discovered that unlike typical B. cereus, those strains pathogenic for insects possessed a rather peculiar sporangium in which the spore may lie obliquely rather than parallel to the sporangial walls. Although this observation does not necessarily mean that virulence is associated with the oblique spores, it probably does indicate a significant difference in the strains of $B$. cereus concerned. For this and other reasons it has been thought 
wise to retain, for the time being, the name Bacillus thuringiensis Berliner for those strains generally resembling $B$. cereus but having oblique spores and showing pathogenicity for insects.

Effect of Bacillus "C" on Scale Insects. What proved to be another strain of Bacillus cereus, but not the Bacillus thuringiensis type, is the so-called Bacillus "C" of Sokoloff and Klotz $(1941,1942)$. These workers first isolated the bacillus from soil, and later from the California citrus red scale, Aonidiella aurantii (Mask.), for which they claimed it was pathogenic. According to them the organism was capable of invading and destroying the adult scale insects on lemons under certain experimental conditions. They believed that the lethal effect was related to the reduction of nitrate by the bacterium within the body of the insect. In 1947, the author, assisted by K. D. Snyder and K. M. Hughes attempted to repeat the results obtained by Sokoloff and Klotz with a strain of the bacillus obtained from L. J. Klotz on June 2, 1945. Although similar lethal effects were obtained with broth cultures of the organism, the reported invasive properties of the bacillus could not be demonstrated. When red-scale-infested fruit (grapefruit and lemons) or potatoes were immersed in 48-hour broth or peptone-water cultures of Bacillus "C" for 16 hours, then incubated at $28^{\circ} \mathrm{C}$ for from 7 to 14 days, the insects did die in numbers considerably greater than did untreated controls or controls which were placed in sterile media. This killing effect usually extended to 100 per cent of the scale insects. However, these dead insects were never found to contain the bacteria within their bodies. Bacteria were frequently observed underneath the waxy covering of the scale, and in crevices and folds of the insect's integument, but not in the internal body tissues. Examination of the insects for the presence of the bacteria were carried out by means of stained smears and histological sections.

Particularly interesting was the fact that the lethal effect could be demonstrated with strains of Bacillus cereus isolated from soil and from human sources as well as with other bacteria including Bacillus subtilis Cohn emend. Prazmowski, Serratia marcescens Bizio, Escherichia coli (Migula), Micrococcus pyogenes var. aureus (Rosenbach) (=Staphylococcus aureus Rosenbach), and Sarcina lutea Schroeter. Except for Bacillus cereus and Bacillus subtilis, none of these is a sporeformer nor is any related to.Bacillus "C." For example, in an experiment designed to compare the lethal effect of broth cultures of two nonentomogenous strains of Bacillus cereus with that of a broth culture of Bacillus "C," the average per cent of dead scales on infested lemons that had been immersed in the cultures for 16 hours and then incubated for 7 days at $28^{\circ} \mathrm{C}$ was as follows : scales on lemons immersed in Bacillus " $\mathrm{C}$ " cultures, 82 per cent dead; in B. cereus culture No. 1,83 per cent dead; in $B$. cereus culture No. 2, 86 per cent dead; and in uninoculated broth (but in which a small amount of growth gradually developed from contaminants on the surface of the lemons), 72 per cent dead. Similar results were obtained using other species of bacteria. In general the procedures and methods used by Sokoloff and Klotz were followed throughout these experiments.

A few cursory experiments indicated that the toxic effect could be obtained in certain, but not all, filtrates of the cultures as well as in cultures from which the bacteria had been removed by centrifugation. Filtration of Bacillus 
"C" cultures through 8-pound Mandler filters appeared to destroy the toxicity of the medium for the red scale. Filtration through Seitz filter-pads only partially destroyed the toxicity. Bacteria separated from the medium by centrifuging at 2000 r.p.m. for 4 hours and resuspended in distilled water killed no more insects than did sterile broth. On the other hand, the supernatant fluid from the centrifuging exhibited a toxicity comparable to that of the original culture. Aeration by bubbling air through a culture of Bacillus "C" for 8 hours just before exposing red scale to it, did not destroy the toxicity of the medium as might have been the case if the insects had died as the result of reduced oxygen tension brought about by the bacteria.

In general, the results of these experiments indicate that the observed killing effect on California red scale is nonspecific in character with regard to the bacteria tested. In other words, it appears that there is nothing special about the killing effect exhibited by cultures of Bacillus "C" (now known to be a strain of Bacillus cereus Fr. \& Fr.). Since other species of bacteria appear capable of bringing about the same results and since no evidence could be obtained showing that the bacillus actually is capable of invading the tissues of the insect, it seems justifiable to conclude that factors other than actual infection are responsible for the mortality. It would appear that the toxicity is more the result of bacterial growth in the medium rather than invasion of the insect's body by the bacteria themselves.

Sokoloff and Klotz (1942) expressed the opinion that the ability of Bacillus " $C$ " to reduce nitrates to nitrites may have something to do with the mortality since "infected" insects contained considerably less nitrate than did uninfected insects. Inasmuch as all species of bacteria tested in our experiments are nitrate reducers it would appear wise to investigate the possibility that the nitrate-reducing enzymes produced by the bacteria may penetrate into or be absorbed by the insects, causing them to succumb to the effects of nitrate reduction in their bodies. It is possible that some of the reduction products could be toxic to the insects. Other nonspecific factors may be considered, such as those having to do with the possible production by the bacteria of certain metabolites which may be toxic to the red scale.

Other sporeforming bacteria (genus Bacillus) have been observed in various insects submitted for diagnosis. For the most part these have not been identified as to species since there was no time or opportunity to test their true pathogenicity in the same insect species from which they were isolated and thus verify them as the cause of the insect's death. The accessions concerned include : an unidentified ichneumonid collected near Patterson, California; grubs of Melolontha sp. from near Beauce, France, and from which two different sporeformers were isolated; Myelois venipars Dyar from Albany, California ; honey bee larvae from Canton, China (in all probability the bacterium observed was Bacillus larvae White, the cause of American foulbrood; this was also indicated by the symptoms and post mortem appearance) ; larvae of the Mediterranean flour moth, Ephestia kühniella Zeller, from Vallejo, California ; larvae of the western grape leaf skeletonizer, Harrisina brillians B. \& McD., from Fort Huachuca, Arizona, and from La Mesa, California. 
Gram-positive cocci (both micrococci and streptococci) have been isolated in significant numbers from diseased or dead insects received in our laboratory. In no case, however, was there any evidence that the coccus was in any way responsible for the morbidity or mortality of the insect.

\section{FUNGOUS INFECTIONS}

Of the 575 accessions so far received for diagnosis, the insects in 195 (approximately 34 per cent) were found harboring fungi of one type or another. It has been expedient for us to identify as to species or genus only about 75 of the strains isolated. A number of others were identified as to family or a higher category. The diagnosis in 86 cases was reported merely as "unidentified fungus present." In the future, it is our intention to diagnose more fully this type of infection by making more complete determinations of the fungi. The fact that many fungi are capable of attacking insects weakened by adverse environmental conditions, or of following a primary infection by another microbial agent, or of growing on the dead bodies of insects, makes us extremely cautious in ascribing to these fungi, in any one case, the role of true pathogens. That a particular fungus is the primary cause of an insect's death can be determined only on the basis of past experience with that species of fungus or by the actual testing of the fungus for powers of pathogenicity.

The entomogenous fungi most frequently encountered were those of the genera Beauveria (Phymatotrichum), Empusa, and Entomophthora. However, important fungi in other genera were also detected and are reported herein. In certain instances where the identity of a fungus was in doubt or particularly difficult, confirmation of our identification or an independent identification was kindly provided by specialists. Particularly helpful have been J. A. Stevenson, P. L. Lentz, and Flora G. Pollack of the USDA, Division of Mycology and Disease Survey, and D. M. MacLeod of the Laboratory of Insect Pathology, Division of Entomology, Canadian Department of Agriculture. Most of the identifications, however, were made in our own laboratory.

\section{Phycomycete Infections}

As a group, the most prominent entomogenous fungi in the class Phycomycetes are undoubtedly those in the order Entomophthorales. Numerous diseased insects for which the cause of death appeared to be one of these fungi have come to us. Frequently our diagnosis was limited to an indication of this probability with no further attempt being made to specifically identify the fungus. Recently we have made it a policy to make identifications more complete.

Entomophthorales Infections. An unidentified Entomophthora was observed on larvae of the wattle bagworm, Acanthopsyche junodi Heyl., received from L. B. Ripley, Cedara, Natal, Africa. The insects were received on July 13, 1948. Ripley first observed the infection in 1923 at Wartburg, Natal, where it caused a high mortality in a heavy infestation of the bagworm. He felt that this disease, along with another fungous infection and a polyhedrosis, was of considerable economic importance in reducing destructive populations of the bagworm. 
Entomophthora sphaerosperma Fres. has come to us from points in California on larvae of the clover leaf weevil, Hypera punctata (Fabr.), collected near Livermore; on an unidentified syrphid fly from near San Jose; on the leafhopper Draeculacephala minerva Ball, from near Edenvale; and on an unidentified species of Sciara from Marin County. Entomophthora aulicae Reich. has been noticed on the salt-mash caterpillar, Estigmene acreae (Drury), collected in Albany, California. Some early workers considered the latter fungus to be synonymous with Empusa grylli (Fres.), but most authorities now consider them distinct. We have found what in all probability is Empusa grylli on grasshoppers (Melanoplus) from Iona, South Dakota, and on camel crickets (Ceuthophilus) from South San Francisco and Berkeley. Empusa aphidis Hoff. is believed to be the pathogen found on dead potato aphids, Macrosiphum solanifolii (Ashm.), sent to us from Parma, Idaho, as well as on specimens of the strawberry aphid, Capitophorus fragaefolii (Ckll.), from near San Jose, California. Houseflies, Musca domestica Linn., and unidentified syrphid flies from Berkeley and vicinity have been found infected with Empusa muscae Cohn.

One accession of the periodical cicada, Magicicada septendecim (Linn.) from South Bloomingville, Ohio, sent to us by A. Abdel-Malek, July 1, 1948, an accession of Okanagana aurora Davis from Nevada submitted July 5, 1949, by H. E. Cott, and three preserved specimens of Platypedia areolata Uhler all were infected with what appeared to be Massospora cicadina $\mathrm{Pk}$. or a closely related species. As is characteristic in this infection, the posterior abdominal segments had sloughed off.

Myiophagus Infections. Among the more primitive fungi, the genus Myiophagus (=Myrophagus) has recently come into prominence with the discovery of the chytrid as an endoparasite in scale insects and other insects in such widely separated localities as Ukrainia, England, Bermuda, Canada, and the United States. Whether or not in all cases the species concerned is Myiophagus ucrainicus (Wize) is not clear. We have examined known infected specimens of Lepidosaphes newsteadi Sule from Bermuda sent to us by E. C. G. Bedford, and of the purple scale, Lepidosaphes beckii (Newm.), furnished us by Fran. E. Fisher in Florida. The form of Myiophagus seen in these specimens appeared very similar to that observed by the author in purple scale sent to us for diagnosis by $\mathrm{P}$. W. Weber who collected the insects from oranges at Wailua, Kauai, Territory of Hawaii. The first chytrid-infected specimens submitted to us by Weber were received and diagnosed on March 6,1950 . This finding constitutes the first to be reported west of the United States or east of the Ukraine. Routine microscopic examination by C. G. Thompson of numerous scale insects of several species in California have so far failed to reveal the presence of the chytrid in this state.

\section{Ascomycete Infections}

Although there are a significantly large number of Ascomycetes that are found on or cause infection in insects, only a small handful of diseased insects submitted to us for diagnosis have been found to harbor fungi of this class.

Yeasts or yeastlike organisms have been observed in several diseased or 
dead insects but in no case could we definitely establish the yeast as the primary pathogen. That yeasts pathogenic ior insects do exist, however, is well known.

A considerable number of Ascomycetes are found on scale insects but the intense interest in this group of fungi a few years ago caused most species to be fairly well known in the localities where they abound. Accordingly, we have been called upon to make very few diagnoses in this connection. However, one such accession should be mentioned. On October 17, 1947, we received from J. L. Gresitt, Canton, China, several specimens of an unidentified scale insect all of which were covered with Sphaerostilbe flammea Tul., thus confirming the presence of this fungus in that part of the Orient.

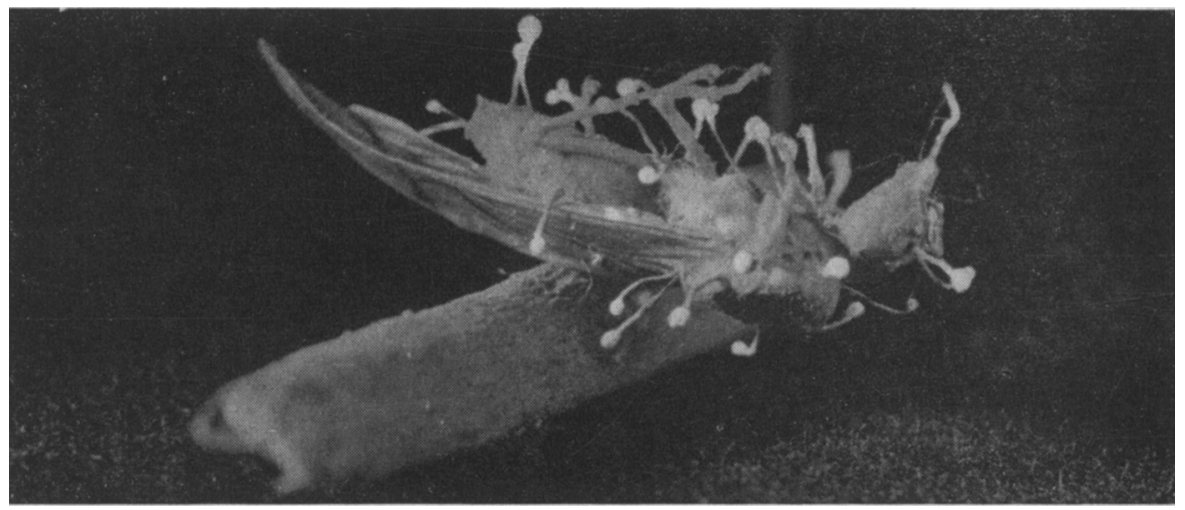

Fig. 6. The fungus Stilbum burmense Mains growing from the body of a winged ant (Camponotus) collected in Burma.

Two interesting species of Cordyceps have been sent to us. One, Cordyceps robertsii (Hooker), was sent to us in 1949 by G. E. Davis who obtained it in New Zealand. The other, Cordyceps sphecocephala (Klotzsch) was received from G. J. Spencer, who collected it near Vancouver, British Columbia, in April, 1941. We received the specimens in February, 1947. In September, 1946 we received from W. L. Jellison a winged ant of the genus Camponotus that he had collected near Myitkyina, Burma. The specimen was forwarded to E. B. Mains, University of Michigan, who described it (Mains, 1948) as a new species: Stilbum burmense Mains (fig. 6). Because of the bicolored synnemata he believed that $S$. burmense may be the conidial stage of one of the species of Cordyceps (on ants) having bicolored clavae.

Although generally not considered pathogens in the usual sense of the word, since they grow and multiply almost entirely on the external surfaces of insects, the fungi designated by the ordinal name Laboulbeniales are interesting and sometimes puzzling structures to entomologists when encountered on specimens in their collections. Very little work has been done on these fungi in the United States since the appearance of Thaxter's monumental monographs on the group between 1896 and 1931. Undoubtedly numerous undescribed species exist, particularly in the western part of the United States, and some of the forms received by us would probably fall in 

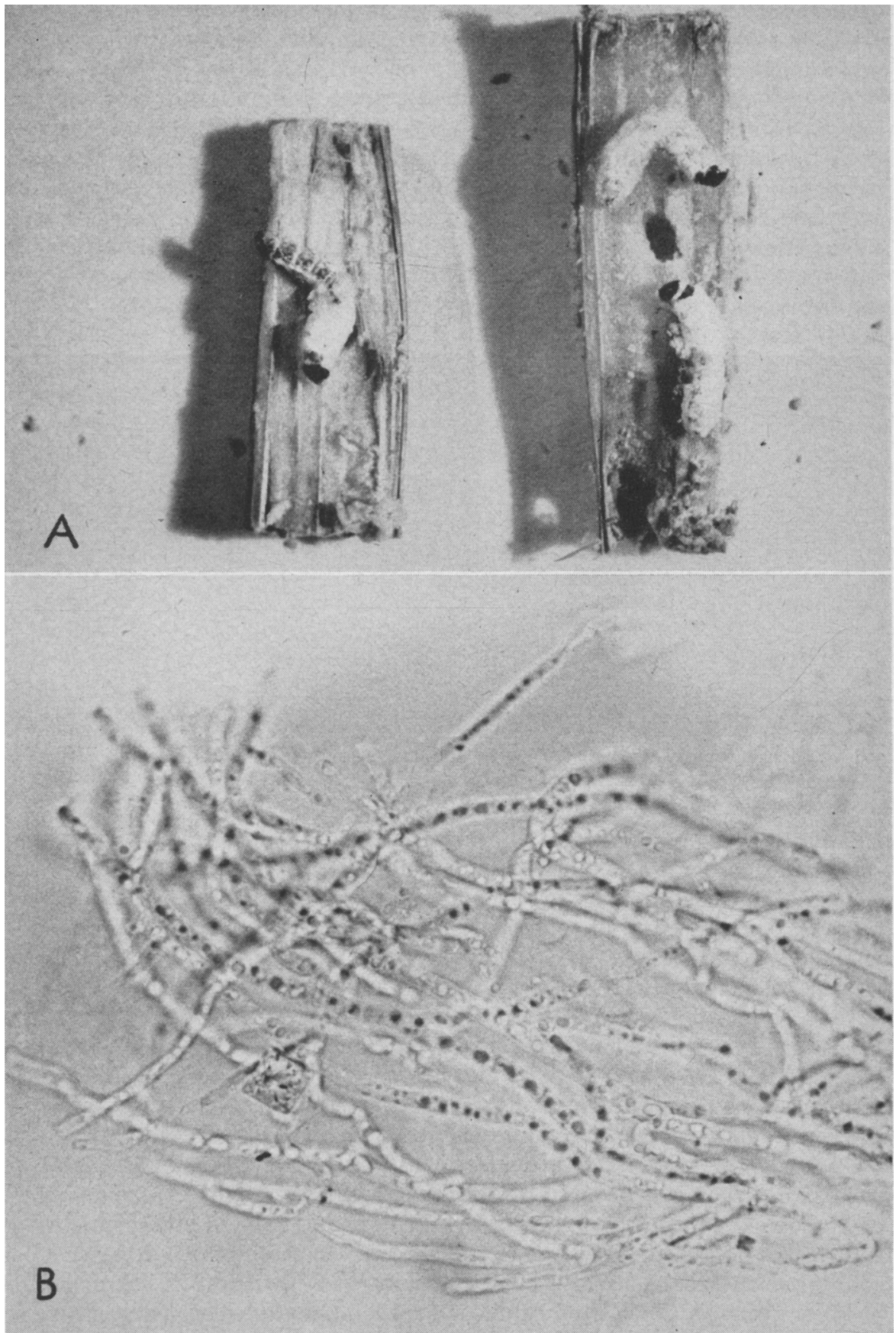

Fig. 7. Beauveria bassiana (Bals.). A. Larvae of the European corn borer, Pyrausta nubilatis (Hbn.), killed by infection with B. bassiana. B. Hyphal threads of B. bassiana. Magnification of $B, 870 \times$. 
this category. We have received species of Laboulbeniales on Besorus sp. collected in Marin County, on Hydroporus coelamboides Fall. and Paracymus sp. from Badwater in Death Valley, and on the mite Bdellonyssus bacoti (Hirst) from Marysville, all in California.

\section{Fungi Imperfecti Infections}

Beauveria Infections. Beauveria bassiana (Bals.) and Beauveria globulifera (Speg.) are both common entomogenous fungi and have been reported on many species of insects throughout the world. The first specimens to be received by our laboratory and found to be infected with one of these species were those submitted in February, 1945, by J. K. Holloway, Albany, California. The insect concerned was Chrysolina hyperici (Forst.); the fungus isolated from several specimens of the insect was Beauveria globulifera. The diseased beetles, recently received from Australia for experiments in the biological control of the Klamath weed, first showed a white fungous growth emerging from beneath the wing coverings; eventually the insects became entirely covered by and embedded in the fungus. The same type of infection apparently has been noted on this beetle in Australia where the insect was introduced from Europe.

Of 29 accessions (constituting a total of 307 larvae) of the European corn borer, Pyrausta nubilalis (Hbn.), received for diagnosis up to December 31, 1950, the majority contained specimens infected with Beauveria bassiana (fig. $7, A, B$ ). Most of these specimens were forwarded to us by W. G. Bradley and K. D. Arbuthnot from laboratories in Ohio and Iowa between the dates of January 21 and August 10, 1950. The larvae had been originally collected from various points in Iowa and Ohio, but the Beauveria infections were not apparent until after the insects had been reared for a while in the laboratory. Although the possibility that some of the borers were infected in the field cannot be dismissed, all indications are that most of the Beauveria infections were acquired in the laboratory. An additional lot containing Beauveriainfected European corn borer larvae, collected in Iowa and held in the laboratory, was received from J. H. Lilly on January 30, 1950. In addition to finding typical B. bassiana on the corn-borer larvae, certain atypical forms as well as cultures that tended to resemble Beauveria globulifera were also isolated. B. bassiana, however, appeared to be the predominating fungus associated with these insects. Of interest is the fact that a large number of Beauveria-infected larvae were also infected with a microsporidian (see table 1 , page 658 ).

That the larva of the codling moth, Carpocapsa pomonella (Linn.), is subject to infection by Beauveria has been reported before by other workers. Our first accession of this type was received on March 9, 1946, from E. G. Linsley who collected the specimen from under the bark of an apple tree in Lafayette, California. On February 27, 1950, two dead codling moth larvae were brought to the laboratory by A. E. Michlebacher who had collected them near Linden, California. Cultures of a Beauveria fungus were isolated from both specimens. Subsequent to this, Michelbacher brought in numerous additional larvae, nearly all of which were covered with white fungous growth. What was apparently Beauveria bassiana was isolated from most of the speci- 
mens although the cultures from some larvae varied slightly from typical $B$. bassiana, others approached B. globulifera, and occasionally a white Aspergillaceae was recovered. Michelbacher, Middlekauff, and Hanson (1951) observed mortalities as high as 69 per cent in the field apparently as the result of infection by Beauveria fungi.

On October 29, 1947, we received a number of Myelois cribrella Hübner larvae from H. L. Parker, Rueil-Malmaison, Seine-et-Oise, France. A subsequent shipment of the same insect was received on April 19, 1949. In both instances the larvae appeared to be killed by infection with Beauveria bassiana. A few Melolontha grubs received from Parker from the region of Beauce, France, in January 1948 also harbored what appeared to be a Beauveria. ${ }^{\circ}$

Also found harboring what appeared to be $B$. bassiana were four specimens of the beetle Colaspis pini Barber collected near Jacksonville, Florida, and a specimen of Dioryctria clarioralis (Wlkr.), apparently collected near Gainesville, Florida, sent in by L. A. Hetrick. An unidentified, and probably new species of Sporotrichum (a genus closely related to Beauveria) was recovered from a dead larva of the mud dauber, Sceliphron servillei (Lepel.), submitted by J. W. MacSwain on October 24, 1945, who removed it from a laboratory rearing jar. The dead larvae had assumed a distinct pink color, and when first isolated the fungus produced a brilliant red, water-soluble pigment that diffused throughout the culture medium. On subsequent transfers the brilliance of this red color somewhat diminished.

Other Fungi Imperfecti Infections. Just as a disease caused by a Beauveria is commonly known as "white muscardine," so it is that the infection caused by Metarrhizium anisopliae (Metch.) is frequently called "green muscardine." At least three of our accessions exhibited the manifestations of this disease, and the causative fungus is probably more prevalent than these three accessions indicate. On October 27, 1947, we received from W. H. Lange, then in Saipan, a specimen of Brontispa mariana Spaeth covered with the green fungous growth characteristic of Metarrhizium anisopliae. V. F. Burk of Columbia, Missouri, on September 25, 1950, submitted several larvae of the cotton leafworm, Alabama argillacea ( $\mathrm{Hbn}$.), that proved to be infected with the green muscardine fungus. A similar finding was made with specimens of the green cloverworm, Plathypena scabra (Fabr.), sent in by F. W. Poos from Mount Jackson, Virginia, on September 26, 1950.

At this point may be mentioned the isolation of Aspergillus flavus Link ex Fr. and Aspergillus flavipes (Bain. \& Sart.) from larvae of a wild bee, Nomia melanderi Cockerell, sent to us from Utah by G. E. Bohart on May 24, 1950.

\footnotetext{
${ }^{5}$ Nematodes of the genus Diplogaster were found in large numbers in the dead bodies of these Melolontha grubs from France. Upon receipt of insects obviously infected with nematodes no attempt has been made to diagnose the disease conditions beyond reporting the presence of nematodes in the specimens. Occasionally we have made an effort to supply the generic name of the nematode concerned. In such cases after making the diagnosis, we have obtained identification or confirmation of our identification from M. W. Allen of the University's Division of Entomology and Parasitology. A species of Diplogaster was also found in what was presumably Reticulitermes virginicus Banks from Florida. The latter specimens harbored, in addition, a species of Rhabditis. A Rhabditis has also been noted in our laboratory in larvae of the omnivorous looper, Sabulodes caberata Guenée.
} 
A. flavus was also isolated from two species of wild bees, Diadasia bituberculata Cresson, and Diadasia consociata Tim., collected near San Diego and Tracy, California, respectively and given to us by J. W. MacSwain in March and April, 1950. Unidentified strains of Aspergillus as well as Penicillium have been isolated from time to time from various insects, but it is felt that in most instances these isolates represent adventitious saprophytes rather than true insect pathogens. Sometimes they were known to be consistent secondary invaders to other morbid conditions.

Specimens of "red scale" were received by us from J. L. Gressitt on November 24, 1947. They had been collected near Taipeh, Formosa, and according to Gressitt were harboring the imperfect fungus "Microcera fujikuroi." No further confirmation of this identity was made in our laboratory.

Unidentified Fungous Infection of Aphids. What may be a Fungi Imperfecti, or possibly a phycomycete (although there is no certainty whatever about this), is a fungous parasite of aphids that has come to us in specimens from three different localities. In February, 1947, E. O. Essig called the author's attention to several mounted specimens of diseased giant willow aphids, Pterochlorus viminalis (B. deFonsc.), that he had collected on August 5, 1911, near Santa Paula, California. In referring to the infection, Essig (1926) states that "a disease which causes the bodies to melt away kills great numbers in Southern California." He recalls observing large numbers of these infected aphids occurring on foliage along the banks of streams in the Santa Paula area. What apparently is the same or a similar disease in the same insect is described by Spencer (1945) as follows: "... [In] September $1941 \ldots$ great patches of aphids appear[ed] again and were shortly attacked by some disease which literally liquefied the bodies into black drops which fell to the ground." As mentioned in a previous publication (Steinhaus, 1949a) microscopic examination of Essig's slides revealed the presence of peculiar conidialike or sporelike bodies indicating that the pathogen was probably of a fungous nature. The spores or sporelike bodies are dark colored, oval-shaped objects with approximate dimensions of 20 by 35 microns (fig. 8 ). A concavity or depression, and sometimes a slight "bending" of the entire spore, is apparent in many instances. Two distinct walls appear to surround the main body of the spore in which two clear, circular, areas resembling fat globules, or more probably nuclei, occur near the center. An attachment structure frequently may be seen at one end but just how the spores arise from the mycelium has not been determined. The mycelium in the preparations at hand is present primarily as fragments. J. N. Couch, of the University of North Carolina, who also examined these slides, thought the fungus might prove to belong in the Fungi Imperfecti, the class Hyphomycetes, and the group Dermatiaceae-Amerosporae. Couch and ourselves, however, have been unable to find anything in the literature which resembles the material on our aphid slides. A more accurate determination of the fungus will probably have to await the study of fresh material.

Subsequent to the above observations, Professor Essig turned over to the writer several slides of the ambrosia aphid, Macrosiphum ambrosiae (Thos.), that had been collected at Mahomet, Illinois, by Janet and William Rapp in September, 1946. These specimens contained spores (fig. 9) very similar in 


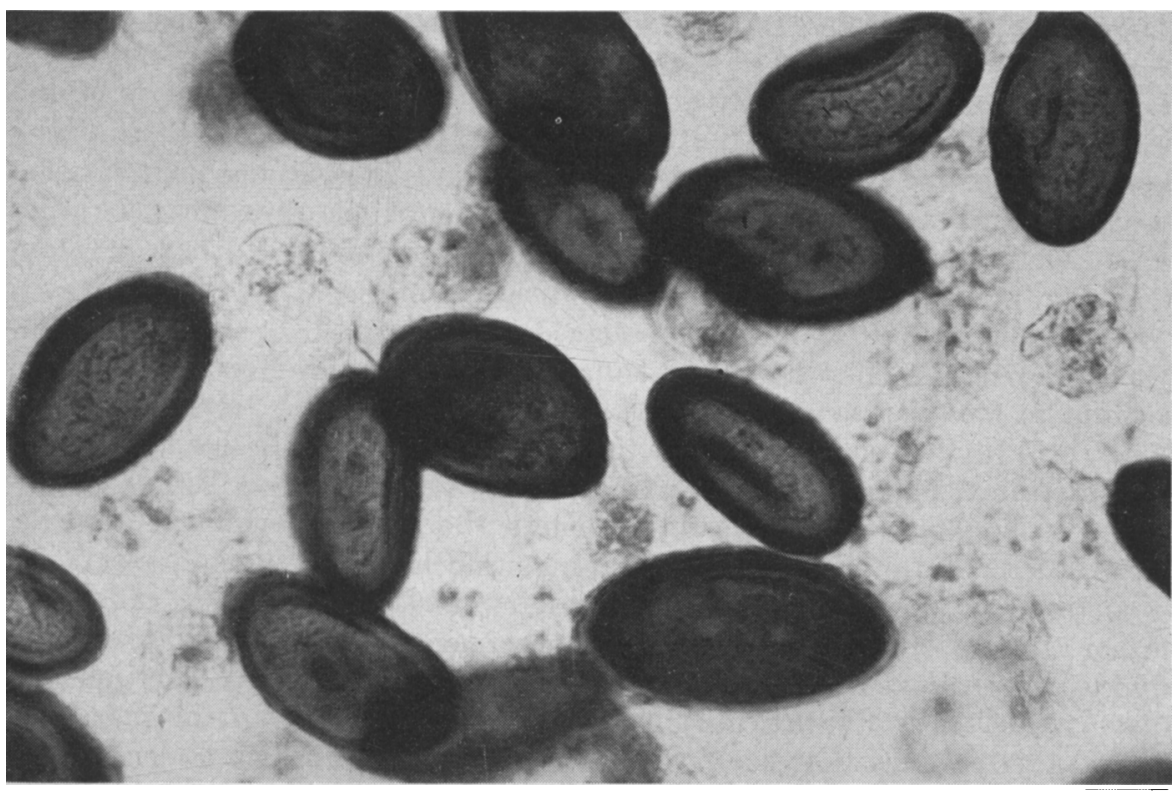

Fig. 8. Photomicrograph of the spores of an unidentified fungus causing a peculiar "melting" disease of the giant willow aphid, Pterochlorus viminalis (B. de Fonse.). See text for details. Magnification approximately $710 \times$.

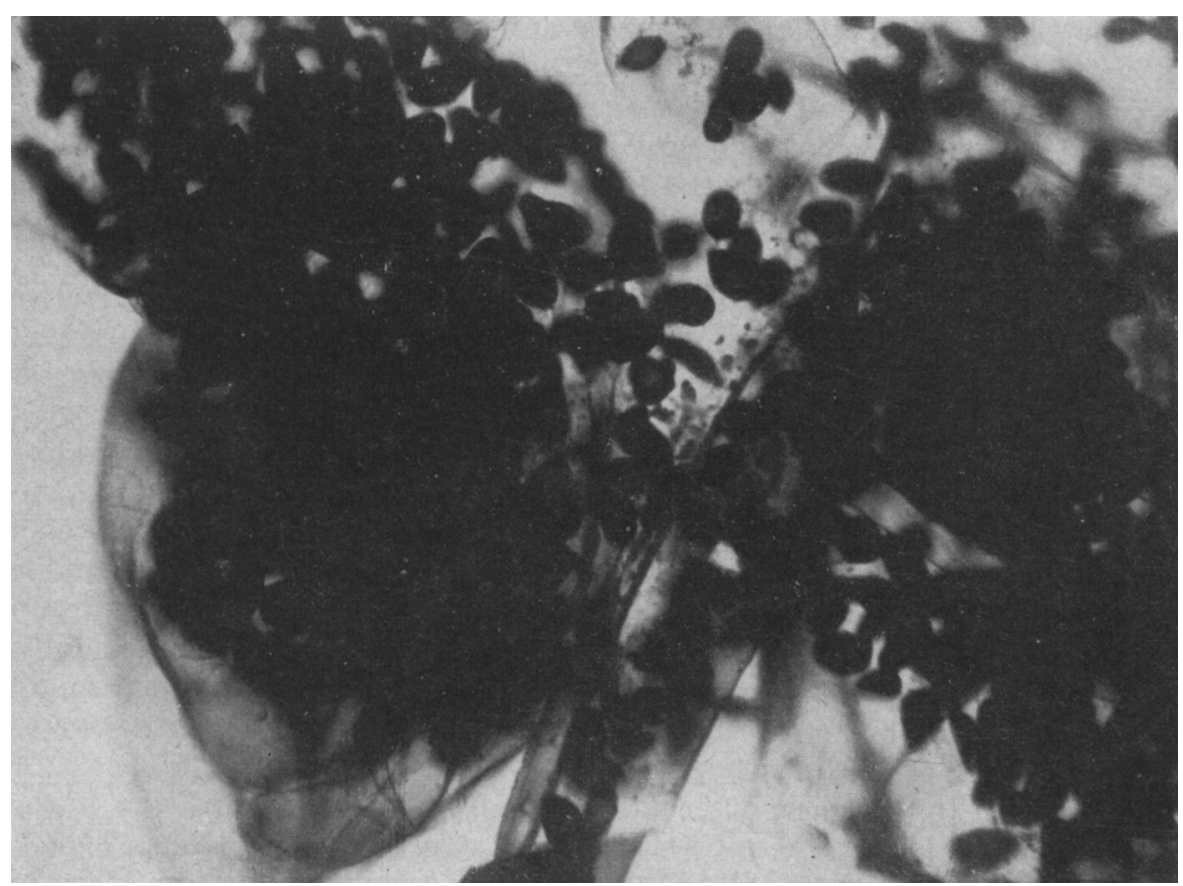

Fig. 9. Photomicrographic view through part of an aphid, Macrosiphum ambrosiae (Thos.), showing presence of fungus spores described in text. Approximate magnification $198 \times$. 
appearance to those observed in the giant willow aphid, and probably represent the same type of disease.

Of particular interest, however, is the fact that on April 27, 1948, we received from N. Plaut a number of diseased aphids, Pterochlorus persicae (Cholodk.) (=Lachnus persicae Cholodk.), collected near Bnei-Berak, Palestine. These aphids appeared to be infected with the same type of fungus as those from California and Illinois, their bodies being filled with spores of similar size, shape, and appearance. According to Plaut, during May, 1947, two heavily infested groves of plums and almonds were completely cleared of the aphid by this disease. The normally dark gray color of the insect becomes a shining brown, and the surface of the body appears moist. When viewed against the light, the body is somewhat transparent. This condition lasts for several days until death occurs. Upon dying the insect hangs by the rostrum and assumes the form of a drop of fluid about to fall. The body wall breaks open at the slightest touch liberating the liquefied, dark brown, body contents. Plaut also submitted specimens of three additional Palestinian aphids (Aphis frangulae Kalt., Aphis (Brachycaudus) amygdalinus Schout., and Aphis sp.) which he suspected of being diseased. None of these aphids, however, appear to be infected with the particular type of fungus just described although some of the specimens were infected with an Entomophthorales.

\section{PROTOZOAN INFECTIONS}

Most of the specimens (approximately 11 per cent of the accessions) we have diagnosed as being infected with a protozoan have been Lepidoptera and Diptera, and most of the protozoa concerned have been of the order Microsporidia. In all, 63 accessions have yielded entomogenous protozoa, all but seven of which have been microsporidia. Of the seven, one (in honey bee adults) was an unidentified protozoan cyst, another (in Dacus cucurbitae Coq.) was a nonpathogenic flagellate of the genus Herpetomonas, and two (in Stenopelmatus longispina Brunner and Culex pipiens Linn. larvae) were eugregarines undoubtedly not seriously pathogenic for their hosts.

The fifth and sixth accessions in this group were obtained in the spring of 1946. They consisted of larvae of two species of Lepidoptera (the Mediterranean flour moth, Ephestia kühniella Zeller, and the Indian-meal moth, Plodia interpunctella (Hbn.), that were being reared in jars in the Division of Entomology and Parasitology, University of California, Berkeley. Both species proved to be infected with a coccidian very similar, if not identical, to Adelina mesnili (Pérez). A more detailed account of these findings has been published elsewhere (Steinhaus, 1947a).

The seventh accession came to us in February, 1947, as a culture of the Indian-meal moth (similar to that just mentioned) that was losing its vitality and slowly dying out. Microscopic examination of the larvae revealed the presence of a schizogregarine (fig. 10) indistinguishable from the published descriptions of Mattesia dispora Naville previously known in the same host insect and in the Mediterranean flour moth in Europe. In the spring of 1949, larvae of the latter insect were found infected in an insectary culture being reared by G. L. Finney, Division of Biological Control, University of California, Albany, California. The Mattesia dispora from this culture was used 


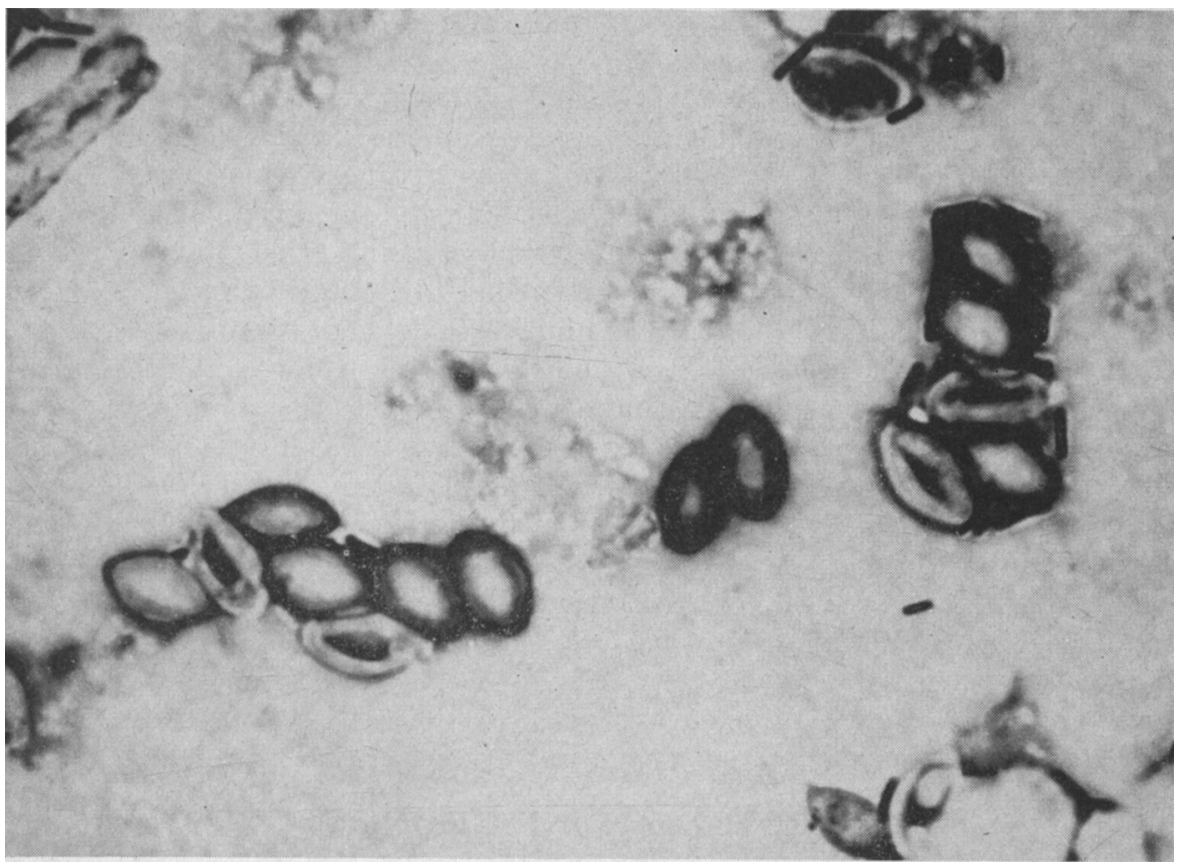

Fig. 10. Spores of Mattesia dispora Naville in smear of body contents of a larva of the Indian-meal moth, Plodia interpunctella ( $\mathrm{Hbn}$.). A few bacteria may also be seen. Magnification approximately $845 \times$.

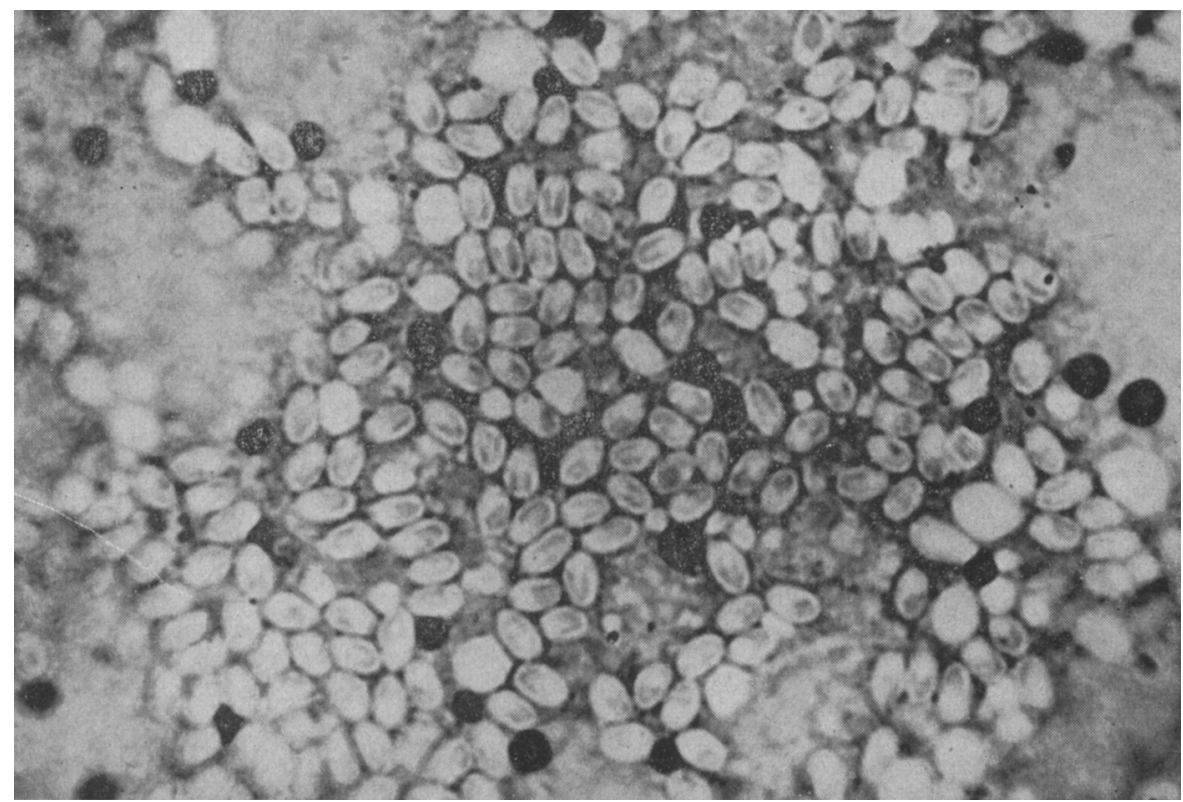

Fig. 11. Photomicrograph of a smear of the internal tissues of the potato tuberworm, Gnorimoschema operculella (Zeller), showing spores of Nosema destructor S. \& H. Magnification approximately $1725 \times$. 


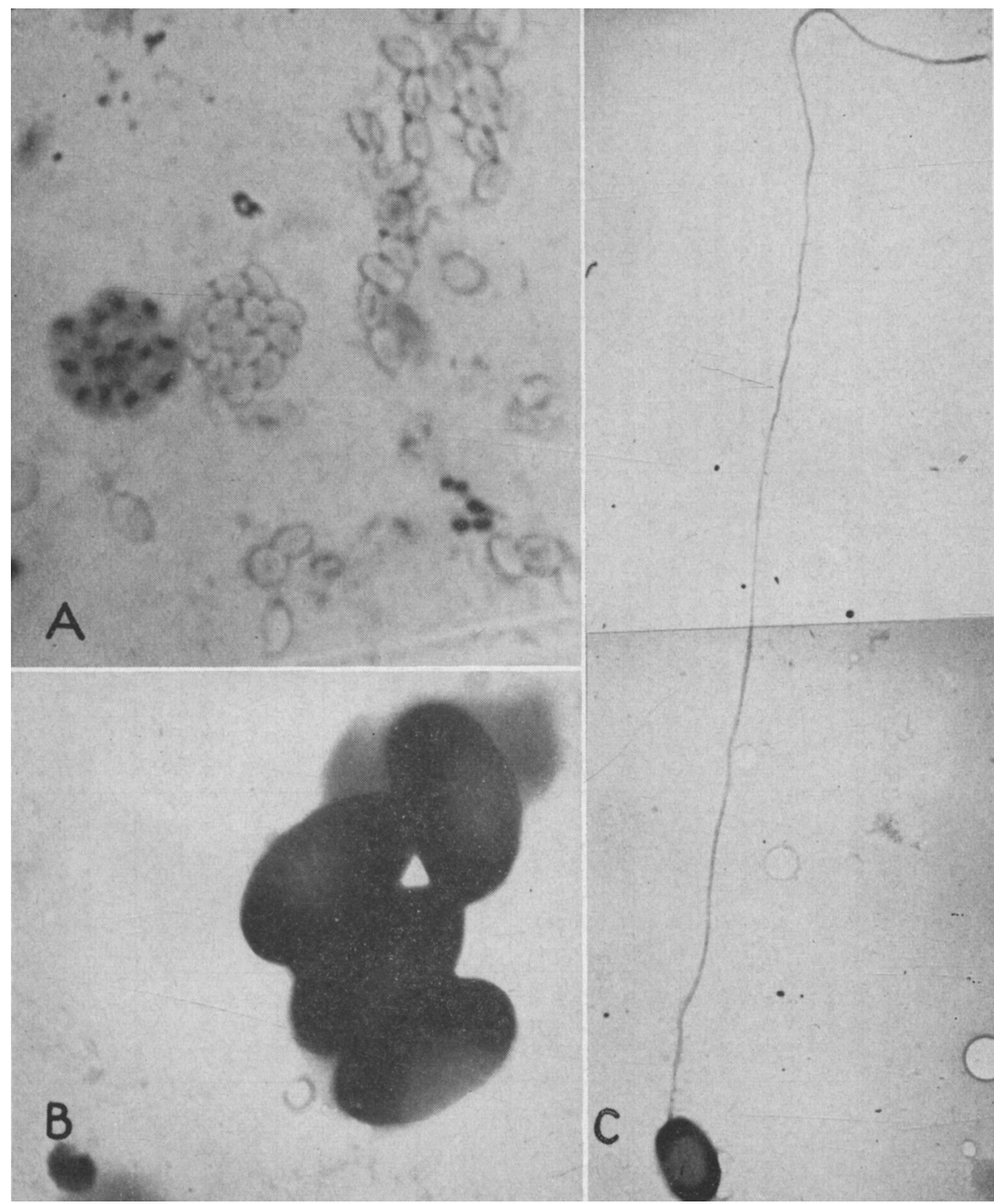

Fig. 12. Spores of the microsporidian Plistophora californica S. \& H. from diseased larvae of the potato tuberworm, Gnorimoschema operculella (Zeller). A. Pansporoblast (left) beside a packet of mature spores. Mature spores seattered throughout right-hand side of photograph. Magnification approximately $2450 \times$. B. Electron micrograph (approximate magnification $14,700 \times$ ) of spores. $C$. Electron micrograph (approximate magnification $6125 \times$ ) of spore with polar filament extruded by pressure.

successfully in an attempt to infect larvae of the alfalfa caterpillar, Colias philodice eurytheme Bdvl., and the potato tuberworm, Gnorimoschema operculella (Zeller).

Microsporidian Infections. Insects in 56 accessions were found infected with microsporidia, of which five genera (Nosema, Plistophora, Thelohania, 


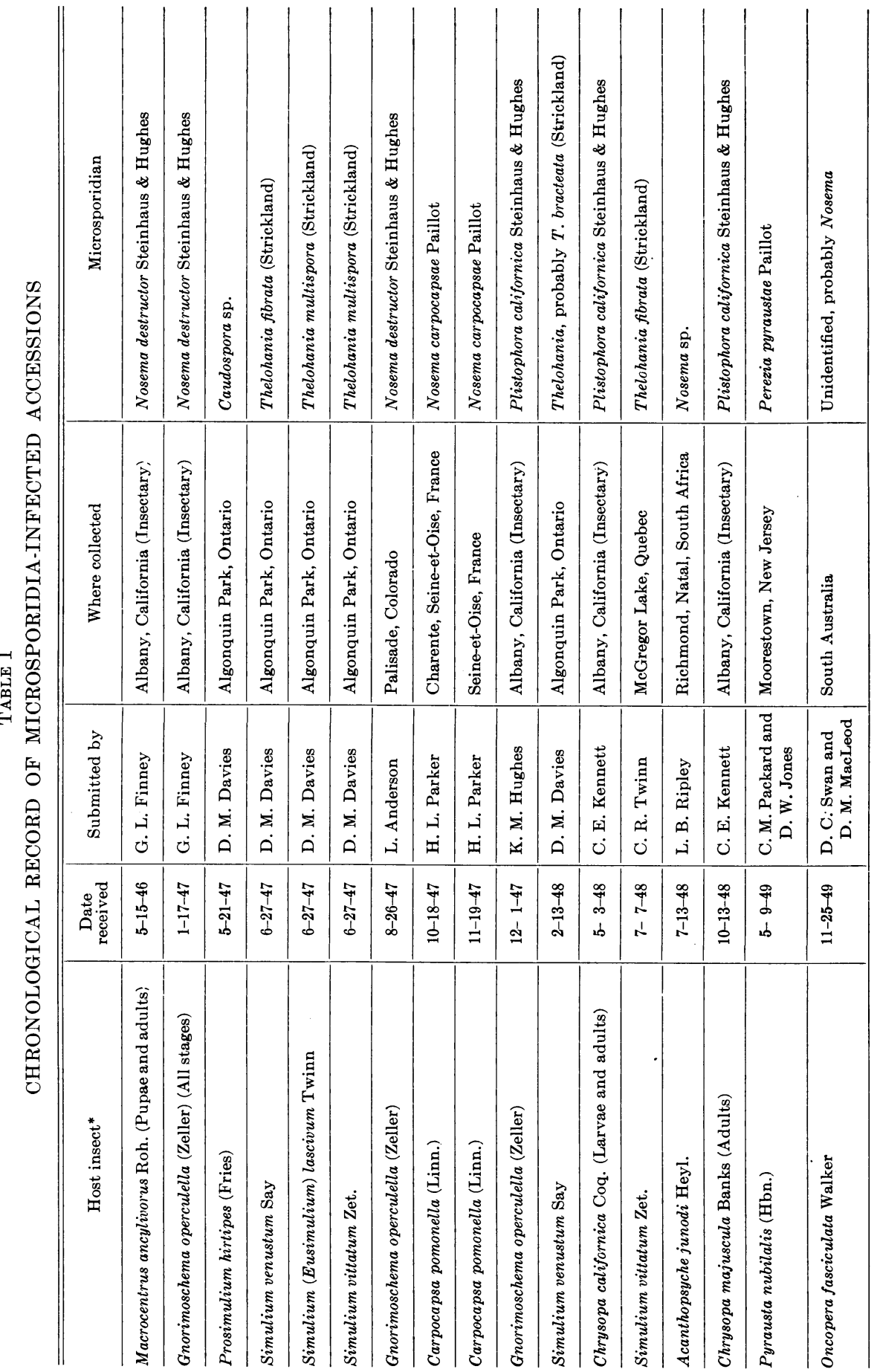




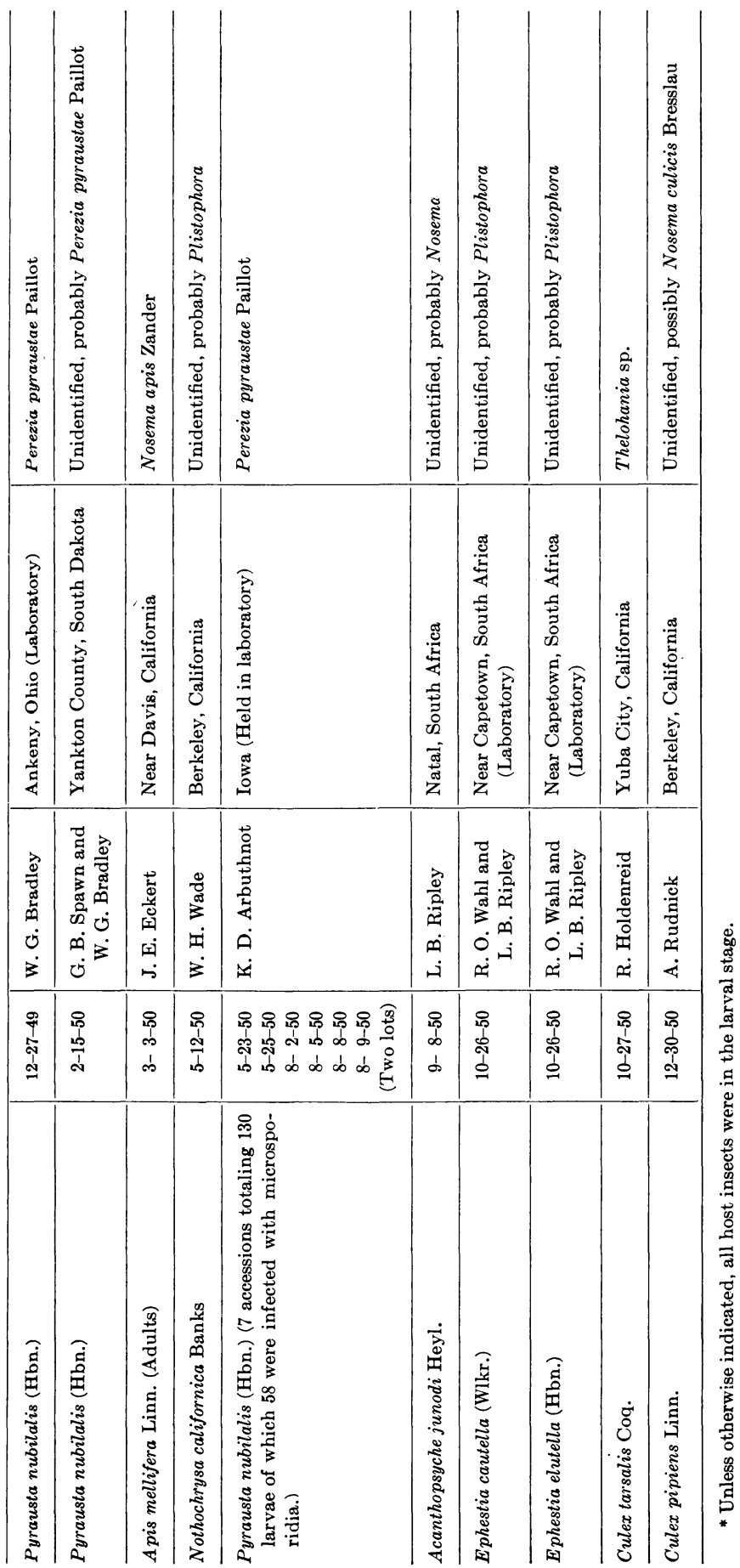


Perezia, and Caudospora) were represented. The details pertaining to these accessions and the accompanying diagnoses are given in table 1 . The accessions of Macrocentrus ancylivorus Roh. and its insectary host, the potato tuberworm (Gnorimoschema), were from a serious outbreak of microsporidian disease in an insectary where these insects were being reared in large numbers. The microsporidia involved (Nosema destructor S. \& H. and Plistophora californica S. \& H.) (fig. 11, fig. 12,A,B,C) have been described in an earlier publication by Steinhaus and Hughes (1949). In table 1 only the first accession of each of these insects is recorded for $N$. destructor, as is only the first accession of the potato tuberworm infected with $P$. californica, there being a total of approximately 20 accessions of microsporidian-infected insects from these sources. Further information relating to the infection of European corn borer larvae by Perezia pyraustae Paillot, the taxonomic aspects of which are being studied by I. M. Hall of our laboratory, will be published elsewhere. Not included in the present report is the finding of several species of microsporidia during the regular course of our research work with insects being reared for experimental purposes in the laboratory.

\section{SYMBIOTES IN HEALTHY INSECTS}

The usual conception of a diagnostic laboratory and its functions would probably not include the examination of healthy insects for the observation of the symbiotes found normally in their tissues. Yet we have been called upon to do this on several occasions and it is, therefore, felt justifiable to summarize in this report some of the more pertinent findings in this connection. The symbiotes with which we are concerned are those microorganisms associated with their insect host either intracellularly in the mycetome or other tissues, or extracellularly in certain gastric caeca. They are usually regarded as maintaining a mutualistic relation with their hosts. The general information pertaining to these microorganisms and the biological relationships they have with the insects that harbor them have been reviewed by Buchner (1930, 1939), Glaser (1930), Paillot (1933), Steinhaus (1946, $1949 a$ ) and others.

\section{Intracellular Symbiotes}

Mealybug Symbiotes. During the fall of 1946 and several times during 1947, Professor Harry S. Smith and his associates at Riverside, California, sent us specimens of the mealybug Pseudococcus maritimus (Ehrhorn) (in California commonly called "Baker's mealybug," with the term "grape mealybug" usually reserved for the form of the insect found on grape) for the purpose of studying the intracellular organisms of the several physiological "races" or "strains" of this insect. It is generally believed that the different races of this mealybug attack different host plants or different groups of host plants ; for example, one form feeds on grape while another feeds on citrus, pear, and apple. Furthermore, the chalcid parasite Acerophagus notativentris Gir. readily attacks the grape form but not the one on citrus. There is no apparent external morphological difference between these two forms or between these and the type form as found on Eriogonum near Santa Cruz, California. It was desired, therefore, to determine whether or not there were any morphological differences in the intracellular symbiotes harbored 
by these different forms or races. If such differences did exist, the classification of these economically important insects might be enhanced by properly correlating these differences. This might lead to a further substantiation of the actual existence of different forms or races of this species of insect.

Accordingly, Kenneth M. Hughes and the writer examined specimens from the three sources (grape, citrus, and Eriogonum) by histological and microscopical techniques. The bacteriumlike symbiotes of $P$. maritimus are con-

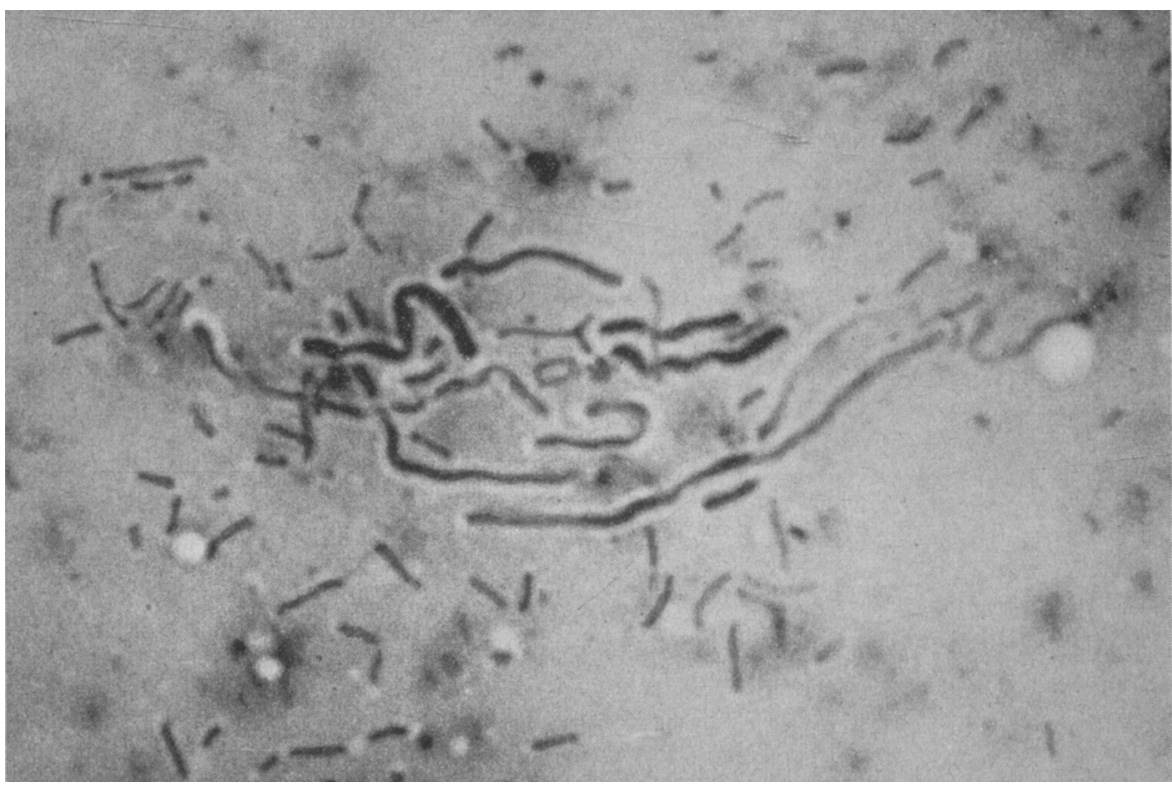

Fig. 13. Photomicrograph of smear of mycetome from Pseudococcus maritimus (Ehrhorn) showing the two types of symbiotes found in specimens of this mealybug collected from grape. Stained with iron hematoxylin. Magnification approximately $1440 \times$.

tained in mycetocytes which make up the mycetome, a relatively large "organ" located in and taking up a large part of the insect's abdomen. Although a considerable number of sections were prepared, the most revealing preparations were obtained by dissecting out the mycetome and making smear preparations of these on ordinary microscope slides. The slides were stained with Giemsa's solution and with iron hematoxylin and eosin. The results, which must be considered as tentative, were as follows :

(1) Mealybug specimens from pear: Symbiotes apparently of only one type; usually large, veriform, and vacuolated with small vacuoles. The size usually ranges from 2 to 3 microns wide by 10 to 20 microns long (sometimes longer, and filamentous and sinuous).

(2) Mealybug specimens from grape: Symbiotes of two types (fig. 13). One type is essentially the same as that seen in specimens from pear; many relatively thick sinuous filamentous forms. The second type is a small (1 to 1.5 microns by 8 to 10 microns), straight rod, sometimes showing darkly staining granules at either end. 


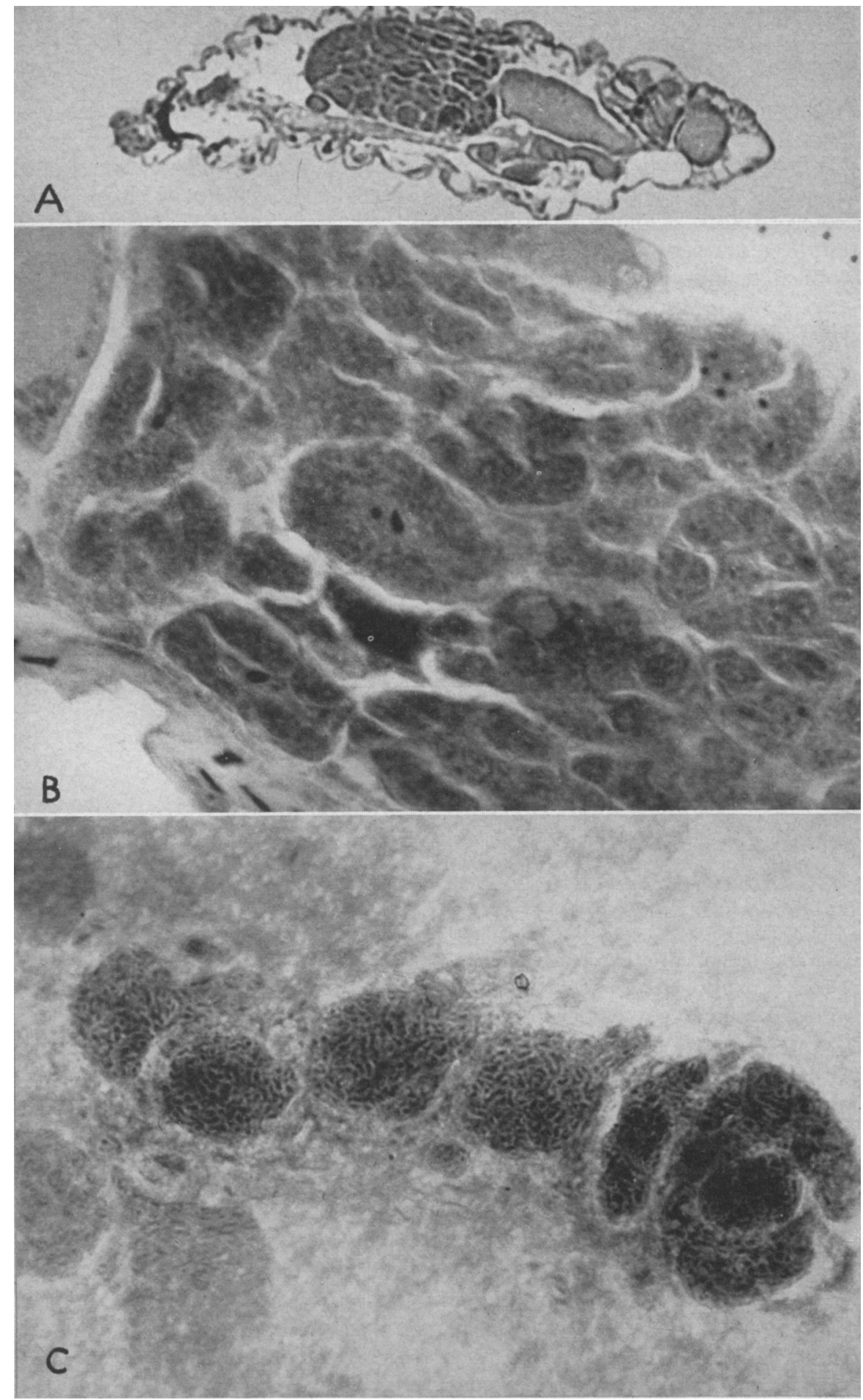

Fig. 14. Sections of mycetome and symbiotes of the citrophilus mealybug, Pseudococcus gahani Green. Stained with iron hemotoxylin. A. Longitudinal section of entire insect showing location of mycetome (large darkly stained structure). $B$. Enlarged view of mycetome showing mycetocytes. $C$. Groups of symbiotes from mycetome. (Figures $A$ and $C$ from author's "Principles of Insect Pathology," 1949a.) Approximate magnifications : $A, 150 \times$; $B, 775 \times ; C, 775 \times$. 
(3) Mealybug specimens from Eriogonum (type) : Symbiotes appear distinctly different from the types seen in specimens from pear or grape, although they sometimes tend to elongate and resemble the pear type of which they may be a variety. They are thick and short ( 4 to 5 microns wide by 6 to 7 microns long), sometimes broadly elliptical or almost spherical. They characteristically contain a single large vacuole located approximately equidistant from the ends. There is possibly a second type of symbiote in these specimens although the true nature of these objects is uncertain. They appear as large, more or less globular, lightly staining forms.

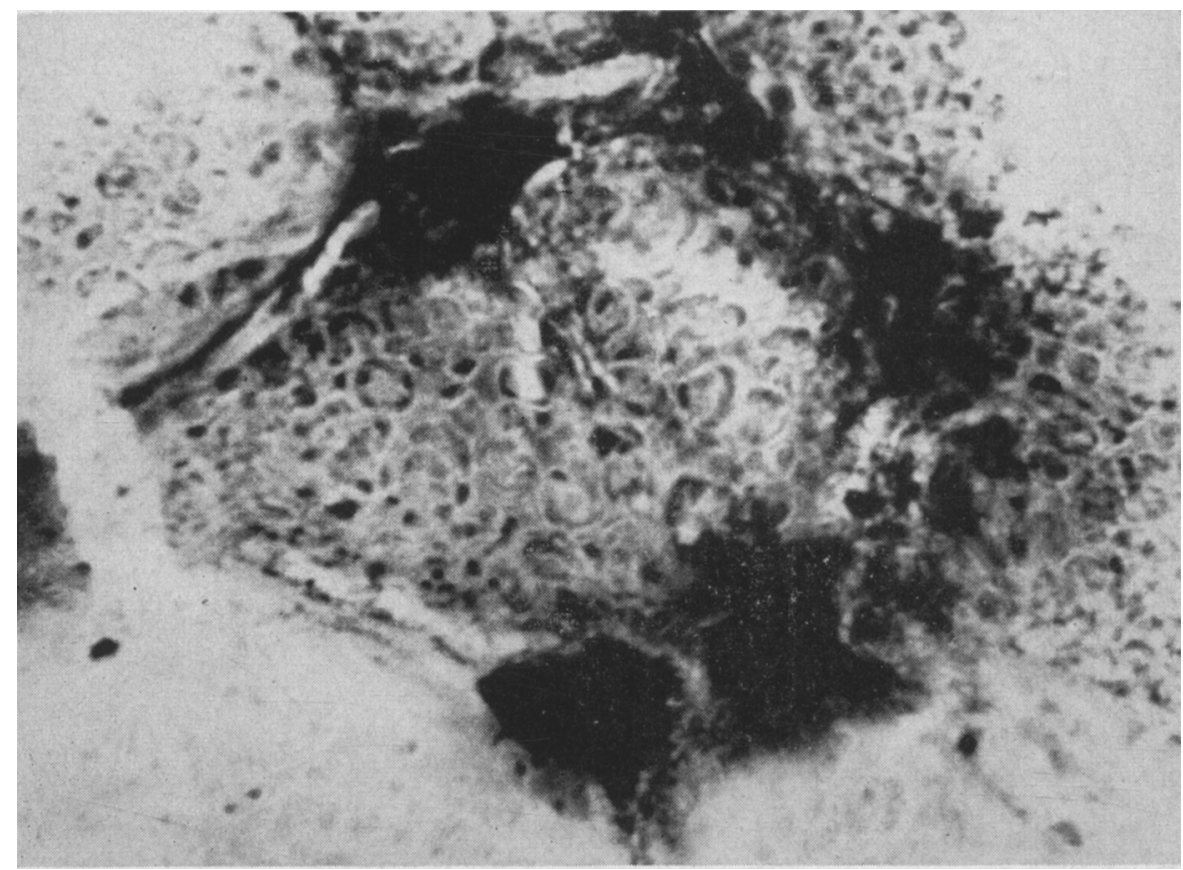

Fig. 15. Smear from mycetome of Phenacoccus gossypii T. \& C. showing the large rounded symbiotes. Stained with iron hematoxylin. Magnification approximately $1090 \times$.

Great caution must, of course, be exercised in evaluating these observations. Whether or not the varied symbiote picture indicates a basic systematic difference in the specimens examined from the three different sources is difficult to ascertain. It is known that the intracellular symbiotes of many insects vary in their morphology according to the diet and stage of the insect, as well as with the particular season of the year. Such phase differences may be what we are seeing in the mealybugs. A similar explanation could possibly be made of the two distinct forms seen together in the case of the grape mealybugs. Thorough study of symbiotes of each of the three groups of mealybugs, under various conditions, should be made before arriving at definite conclusions with regard to stabilized differences in the symbiotes of the three groups.

In addition to Pseudococcus maritimus, other species of mealybugs, all from southern California, have been received at our laboratory, all carrying 
symbiotes of varying size and shape. These include the citrophilus mealybug, Pseudococcus gahani Green (fig. 14), the citrus mealybug, Pseudococcus citri (Risso), the long-tailed mealybug, Pseudococcus longispinus (Targioni), and the Mexican mealybug, Phenacoccus gossypii T. \& C. (fig. 15).

Whitefly Symbiote. Several pupal specimens of the Stanford whitefly, Tetraleurodes stanfordi (Bemis) were brought to the laboratory by J. W.

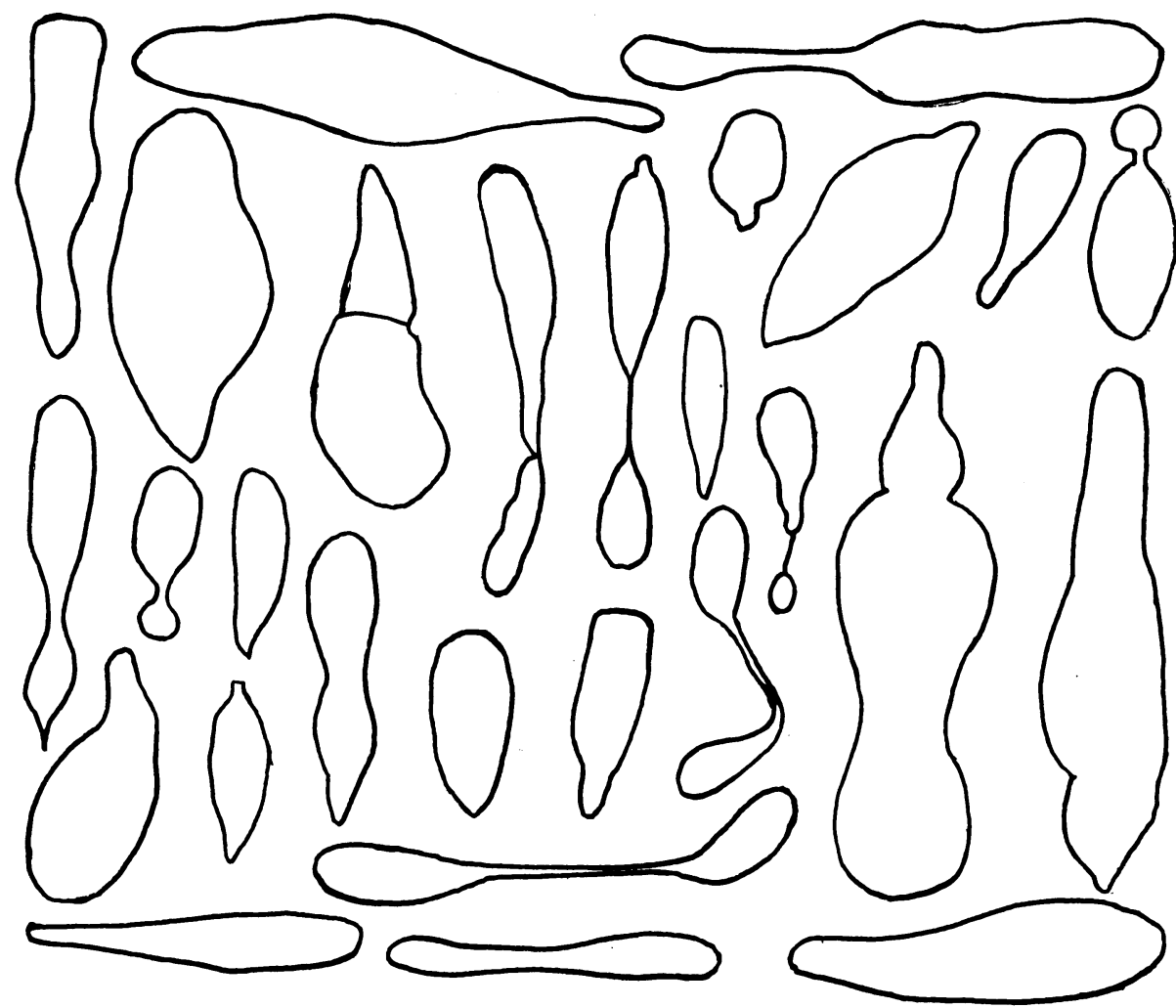

Fig. 16. Diagrammatic representation of the symbiote from the nigra scale, Saissetia nigra (Nietn.), showing in outline some of the various shapes encountered in smear preparations. Not necessarily drawn to seale.

MacSwain on December 14, 1945; they were collected from live oak trees in the vicinity of Berkeley, California. Microscopic examination of the mycetomes revealed the presence of long rodshaped symbiotes of somewhat beaded appearance. The rods were not of a rigid shape, each one having a soft curve or two. The approximate range of dimensions was 1.0 to 1.2 by 5.0 to 10.0 microns. Some filamentous forms were in the neighborhood of 25 or 30 microns.

Symbiotes in Scale Insects. On December 9, 1944, Michael Doudoroff of the University's Department of Bacteriology supplied the writer with an Aralia branch (taken in Berkeley, California) the leaves of which were well covered with the nigra scale, Saissetia nigra (Nietn.). By merely crushing specimens 
of this insect on a slide, yeastlike symbiotes (fig. 16) could be seen in stained as well as wet mount preparations. Hemolymph and connective tissue smears also revealed the presence of the symbiotes which usually occur singly but also in pairs connected by strands of protoplasm of varying lengths. The approximate dimensions are 3.0 to 5.0 by 10 to 15 microns. A nuclear structure is usually visible in a rather granular cytoplasm that also contains from 1 to 4 vacuoles and several rather large, dark-staining elements, probably volutin. When stained with Giemsa's solution, the cytoplasm stains light

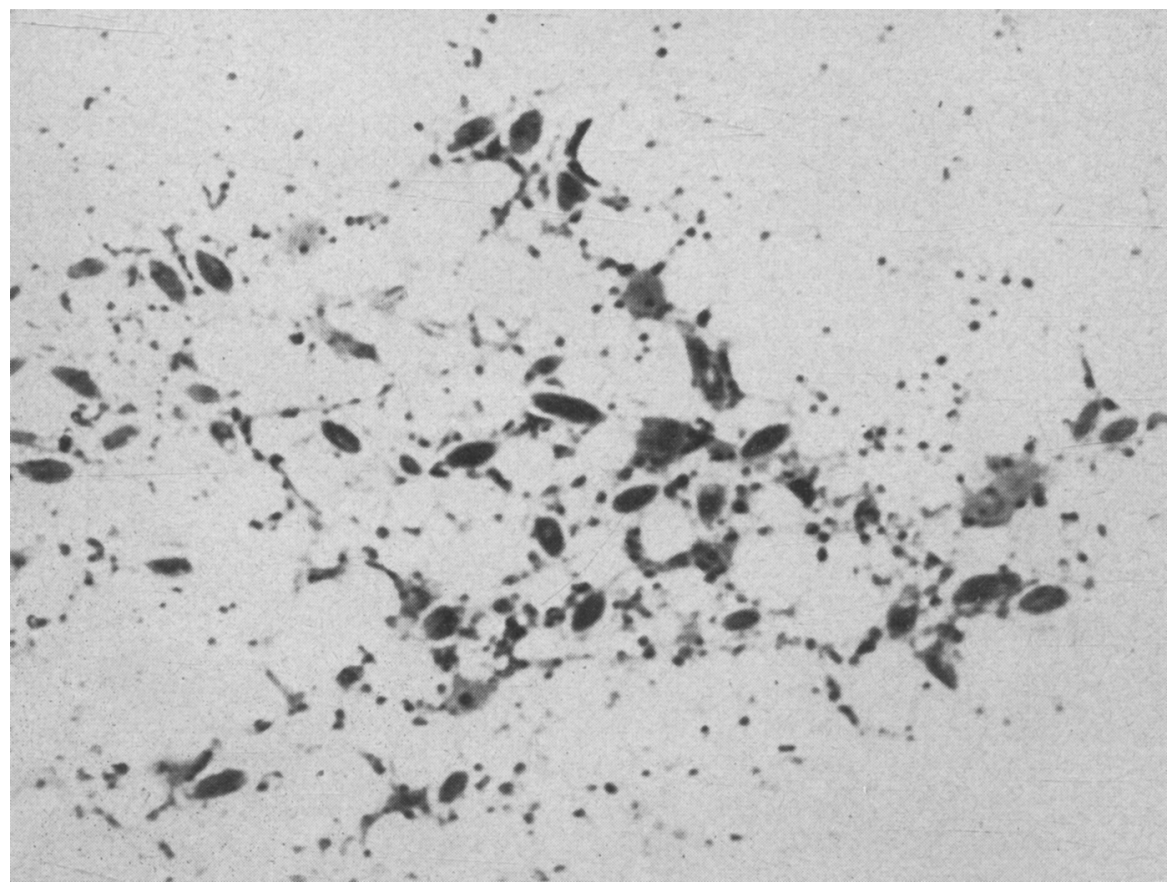

Fig. 17. Yeastlike symbiotes in a stained smear of the body contents of the frosted scale, Lecanium pruinosum Coq. (From author's "Principles of Insect Pathology," 1949a.) Magnification approximately $985 \times$.

blue with the nucleus a pinkish blue. Most cells in an apparently viable condition were gram positive; a few, probably dead cells, were gram negative as were the connecting strands between cells, or their remnants. Attempts to grow the symbiotes on nutrient agar, mannitol agar, yeast autolysate agar with carbohydrates added, and lysed blood agar were unsuccessful. In making these culture attempts it was found that a sooty mold fungus.(Hormodendrum), commonly found on the exterior of scales and their host plants, could confuse the picture inasmuch as this fungus characteristically "breaks down" into its individual yeastlike conidia which somewhat resemble the symbiotes. All stages of the insect, including eggs and crawlers, appear to harbor the symbiote which apparently is present in every individual of the species.

In 1945 and 1946, specimens of the European fruit lecanium, Lecanium corni Bouché, and the frosted scale, Lecanium pruinosum Coq., brought to 
the laboratory from the vicinity of Berkeley were found to carry symbiotes (fig. 17) similar in many respects to those seen in Saissetia nigra. Symbiotes of this type are not found in the hemolymph of armored scales (Diaspididae) which have been reported to harbor more rounded or oval symbiotes in mycetocytes situated throughout the fat tissue. Confirmation of the absence of the type of symbiote found in the soft scales is indicated by our failure to find such organisms in the hemolymph of Lepidosaphes ulmi (Linn.), Aonidiella aurantii (Mask.), Aspidiotus camelliae Sign., and Parlatoria oleae (Colvée).

\section{Caecal Symbiotes}

Harlequin Bug Symbiote. Opening into the posterior end of the midgut of many Hemiptera, especially the higher Hemiptera, are numerous saclike appendages, frequently called "gastric caeca," of various shapes and sizes.

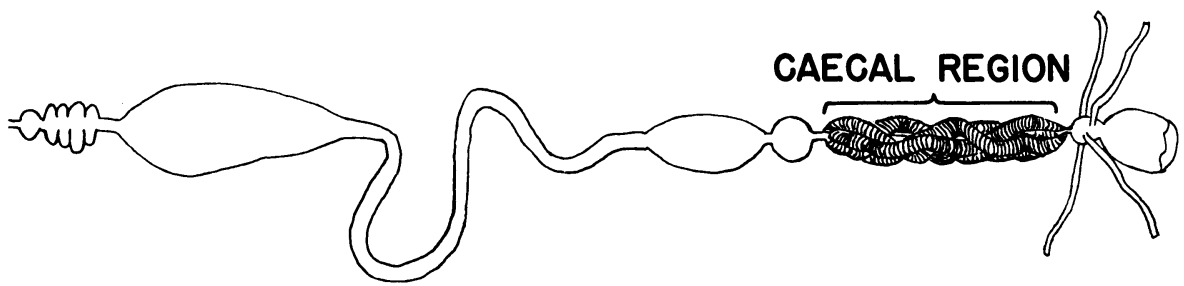

Fig. 18. Diagrammatic sketch of the alimentary tract of the harlequin bug, Murgantia histrionica (Hahn), showing the major parts of the alimentary tract, including the eaecal region (very diagrammatic).

These caeca harbor large numbers of bacteria, each species of insect apparently carrying a distinct and frequently morphologically characteristic strain or species of bacterium. Our direct introduction to this type of symbiotic arrangement came in July, 1944, when E. Gorton Linsley kindly furnished the writer enough living specimens of the harlequin bug, Murgantia histrionica (Hahn), collected in Lafayette, California, for us to initiate a culture of them on potted cabbage and cauliflower plants. A subsequent accession was received from Ray F. Smith on March 19, 1947, collected near Firebaugh, California. The plants and bugs were kept in a cheeseclothscreened rearing cage at room temperatures $\left(22\right.$ to $\left.25^{\circ} \mathrm{C}\right)$. Upon microscopic examination, the caeca of the harlequin bug were found to contain large numbers of a bacterium of such interesting morphology that it was decided to carry the study a bit further. Furthermore, this would perhaps give us an opportunity to revaluate some of the observations made by Glasgow (1914) on the same symbiote.

Before studying the bacterium itself it was thought desirable to determine by dissection the general and gross morphology of the bug's alimentary tract (fig. 18), particularly the region of which the caeca were a part. No significant differences were noted in the general morphology of the alimentary tracts of the male and female insects except that the tract of the male in somewhat smaller. The coecal area especially is smaller in the male than that in the female. The caeca themselves appear to be small outpocketings of the gut 

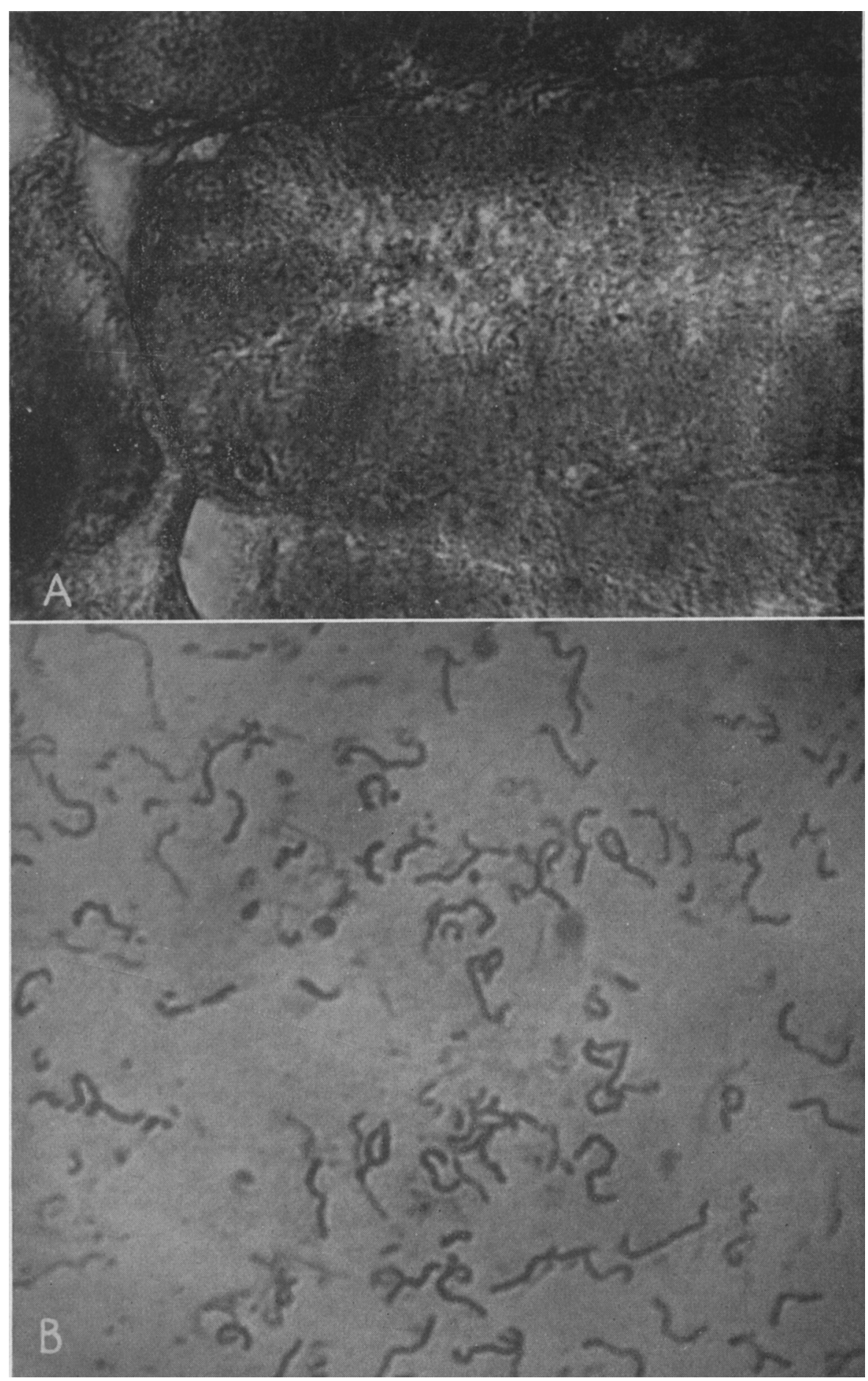

Fig. 19. Caecal bacteria of the harlequin bug, Murgantia kistrionica (Hahn). A. Stained histological section through gastric caeca showing, in one of the compartments, how densely it is packed with bacteria. Magnification approximately $950 \times . B$. Bacteria from caeca as they appear in smear stained with Giemsa's solution. Most of the forms in this particular preparation are of the type that stains uniformly. Magnification approximately $1460 \times$. 
arranged in linear fashion and somewhat spirally about the gut lumen. Their compartmentalization is well demonstrated in cross section (fig. 19,A). In the adult insects the caeca are ordinarily white or cream colored although sometimes they may have a distinct pink or salmon cast. The lower fifth of the caeca of an occasional female was a distinct yellow while the upper fourfifths was the usual cream color. In one male specimen the caeca had a faint greenish yellow tint. Occasionally the caeca in the male appear to be less opaque than in the female. In the immature bugs, particularly those of the

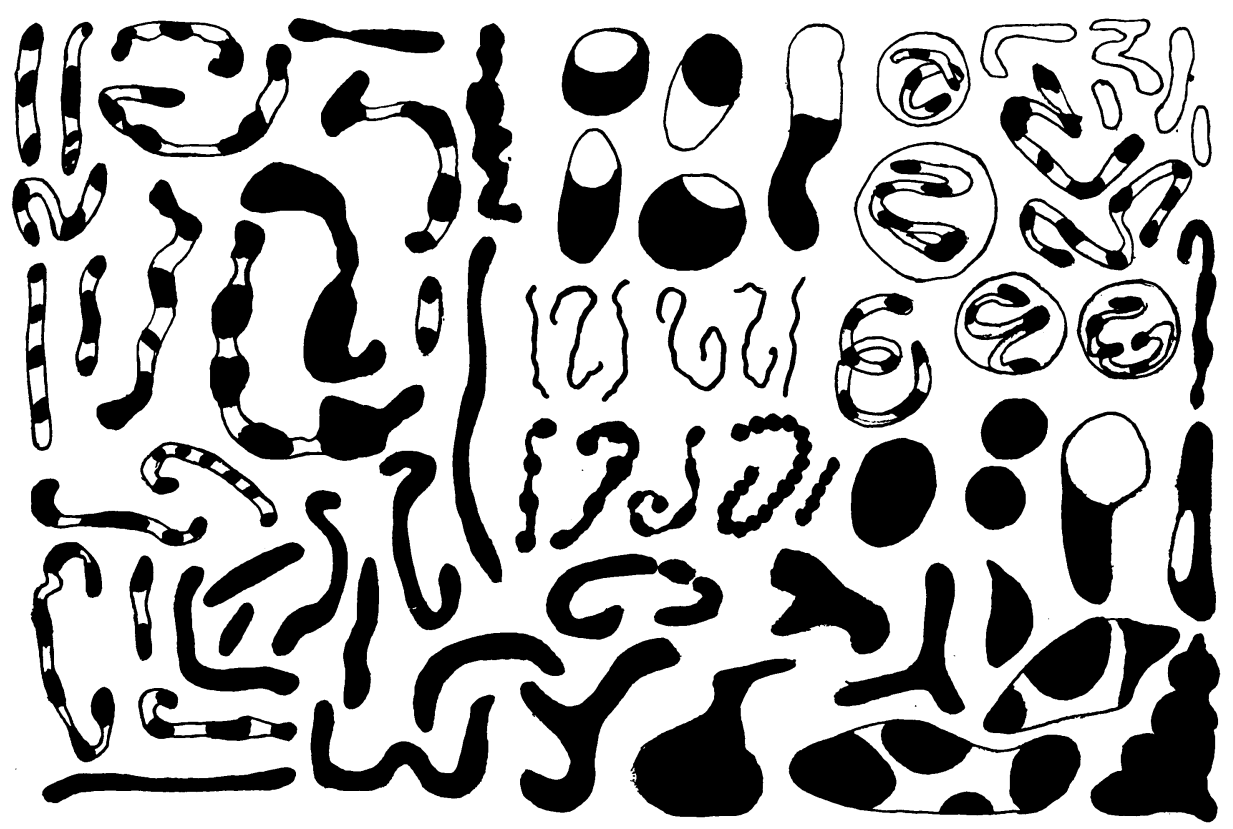

Fig. 20. Some of the various forms of the symbiote found in the caeca of the harlequin bug, Murgantia histrionica (Hahn). Not necessarily drawn to seale. Those forms toward the left side of the drawing are found more frequently than those toward the right side. It is possible that some of the latter are artifacts or aberrant forms.

first and second instars, the caeca were a bright reddish orange. Inasmuch as no careful study of the coloration of the caeca was made with regard to the sex or stage of the insect, we are not in a position to generalize concerning the correlation.

Microscopic examination of the symbiotes themselves revealed much of interest from the morphological point of view. Upon smearing out the caecal contents of an adult insect the large twisted, bent, and convoluted forms shown in figure $19, B$ are prominent. In our preparations most of the organisms were distinctly banded although the solid or uniformly staining forms depicted by Glasgow (1914) were also frequently present. The banded forms suggested giant diphtheroids, the bands staining dark purple with Giemsa's solution which usually gave the uniformly staining type a light blue color. That these organisms probably are not closely related to the gram-positive diphtheroid group is indicated by the fact that they stain gram negatively. 
The size of the symbiotes varies greatly. Lengths all the way from 1 or 2 microns up to 25 to 30 microns were common and occasionally forms approaching 100 microns in length were noted. The usual dimensions, however, are about 1.8 to 3 by 10 to 15 microns. Particularly intriguing were certain bizarre involution forms quite different from but probably stages of those just described. Their exact relation to the large banded form is not, however, very clear. As shown in figure 20, some were spherical bodies partially clear and partially dark, others were elongated and bulbous, still others were ex-

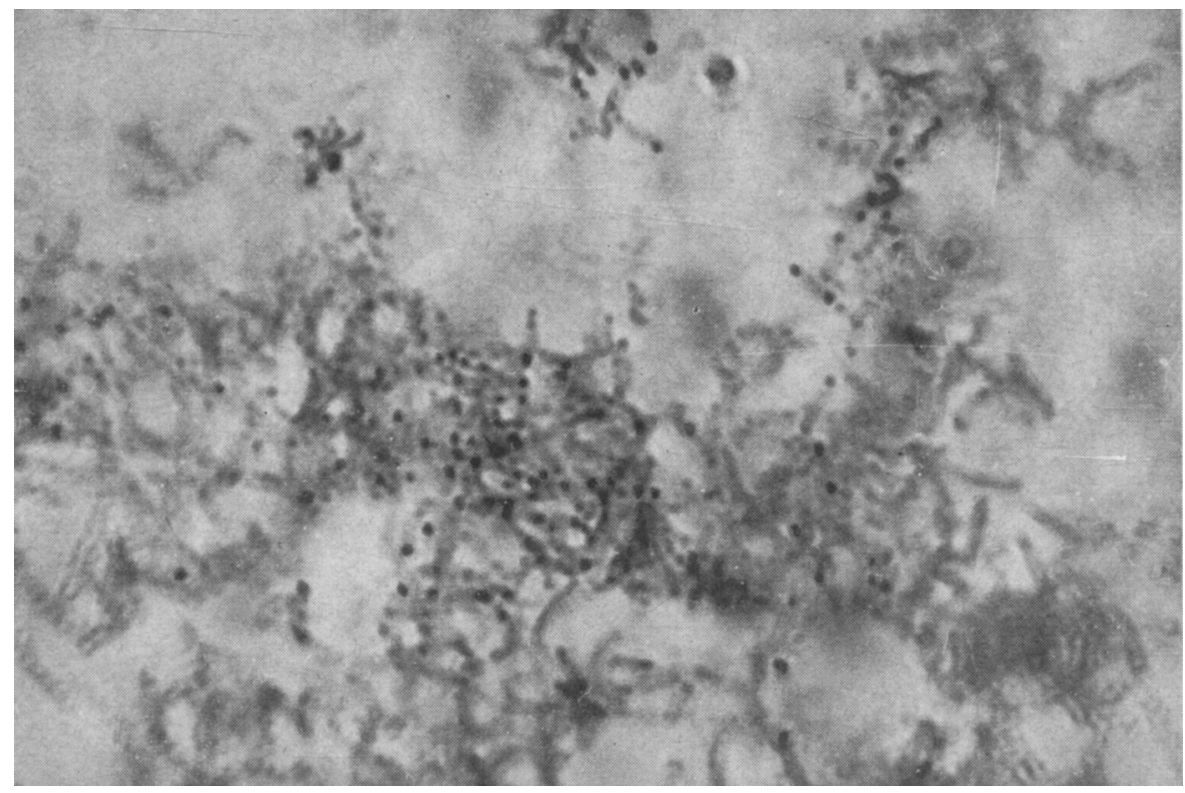

Fig. 21. Symbiote from the caeca of the Say stink bug, Chlorochroa sayi Stål. Magnification approximately $2000 \times$.

tremely thin elements. In a considerable number of instances what apparently was a long banded form was rather tightly convoluted or folded within what appeared to be a thin limiting membrane of some kind. These latter forms were best seen in wet-mount preparations.

A few attempts were made to grow the symbiotes on artificial media. In light of Glasgow's numerous unsuccessful efforts toward this end, it is perhaps not surprising that our rather cursory attempts failed. The following media were tried : nutrient agar, North's gelatin agar containing 2 per cent powdered ox blood, cabbage infusion agar, and nutrient blood agar. In almost all the culture attempts the media remained sterile after inoculation. Except for the symbiotes no other bacteria are found in the guts of these insects. (An unidentified flagellate was observed in one female.) That the symbiotes may exert an antibiotic effect of some kind on other bacteria entering the alimentary tract is a possibility.

Symbiote of Say Stink Bug. Another pentatomid, collected by K. D. Snyder from near Westley, California, on April 8, 1947, was found to have caeca morphologically similar to those charactertistic of the harlequin bug. This 
species was the Say stink bug, Chlorochroa sayi Stål. The symbiotes, however, were quite different from those found in the harlequin bug. Instead of being large convoluted forms, they are smaller (approximately 0.9 to 1.2 microns wide by 3.0 to 12 , usually 6 to 8 microns long) and more uniform in size and shape. They are distinctly diphtheroidal in appearance, each rod usually containing several metachromatic granules (fig. 21).

Symbiotes of Cactus Bugs. On April 7, 1947, D. H. Bixby submitted to the laboratory several specimens each of the cactus joint bug, Chelinidea tabulata

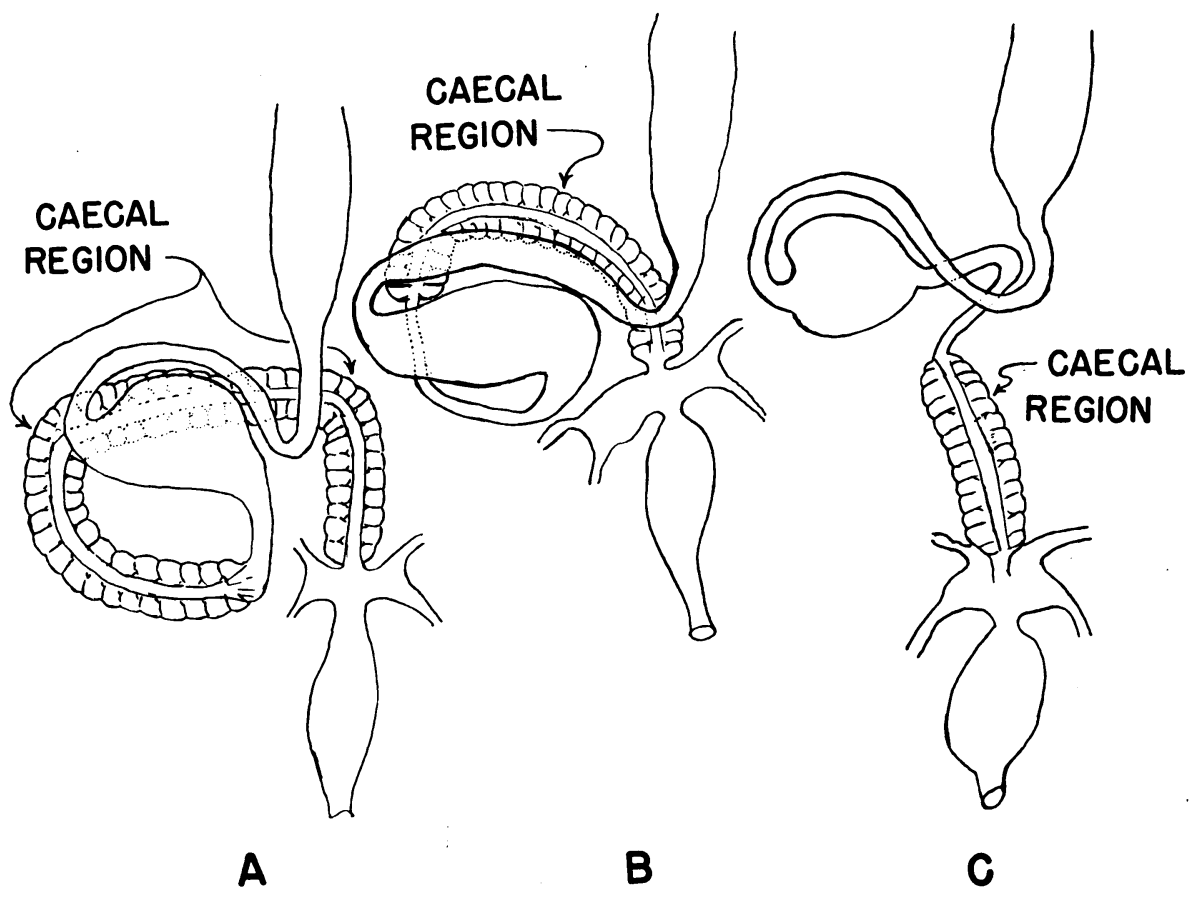

Fig. 22. A rough and very diagrammatic sketch of the general morphology of the alimentary tracts of Chelinidea tabulata (Burm.) ( $A$, female; $B$, male) and Chelinidea vittiger Uhler $(C$, male), showing location of caecal regions.

(Burm.), and Chelinidea vittiger Uhler, being reared for investigational purposes by R. L. Usinger of the University's Division of Entomology and Parasitology. The two strains were originally brought from Texas by Harry $\mathrm{S}$. Smith. We were requested to examine the insects for the presence of caecal bacteria. The writer was assisted in the examination by K. M. Hughes.

Adult specimens of $C$. tabulata were dissected in order to ascertain the gross morphology and anatomical location of the caeca. The essential features of this part of the insect's anatomy are presented in figure 22 . The caeca of the male appear to be less prominent than those of the female. Furthermore, the caeca of the male do not begin so near to the large division of the gut just preceding that to which the caeca are attached as they do in the female. The testes of this species are bright red (occasionally orange) in color, and the caeca have a reddish color which appears, in some specimens at least, to be 
associated largely with the tracheae, although the caeca themselves may be tinged with red. The dorsal surface of the body cavity may or may not show red pigmentation. In the female of $C$. tabulata the caeca were white to light cream in color. Dissection of a male $C$. vittiger showed the testes to be orange in color but the caeca were white. An orange pigment is also visible along the dorsal surface of the body cavity. The general morphology of the alimentary tract and caeca are similar to that of C. tabulata.

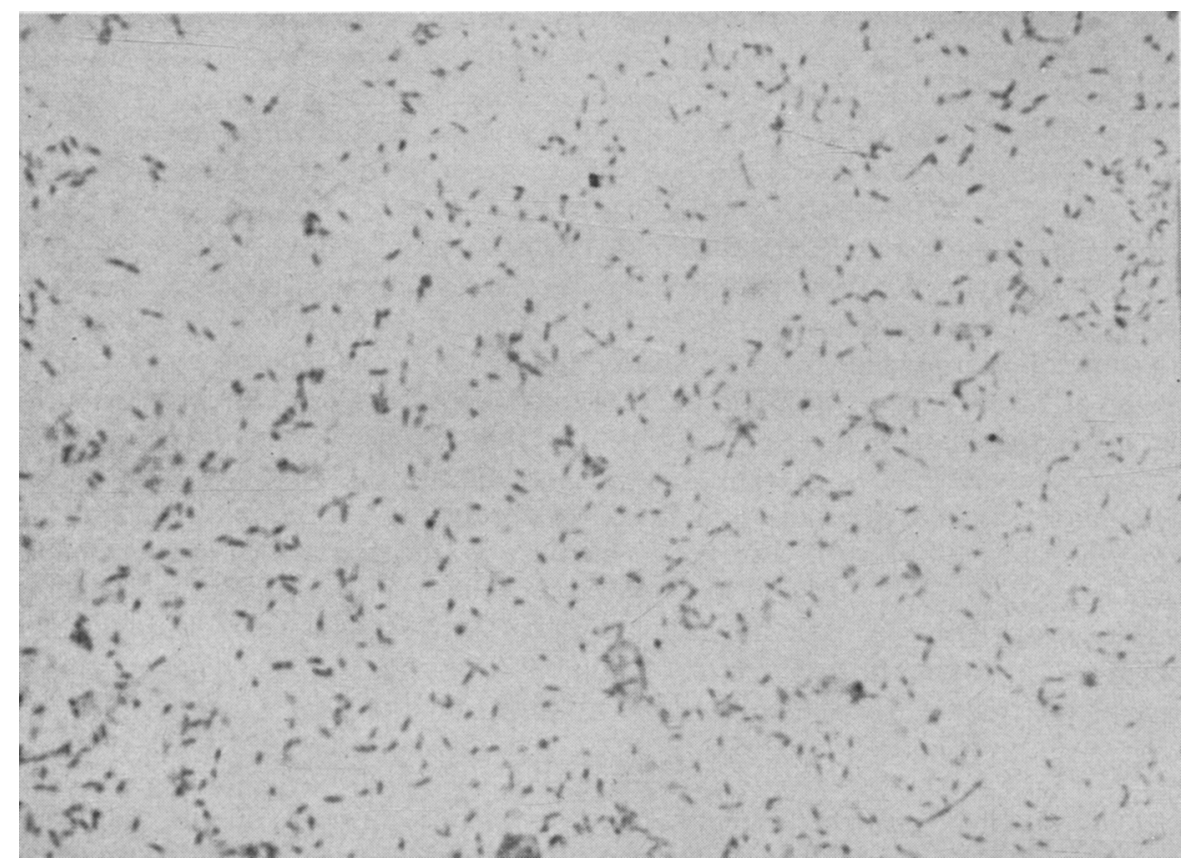

Fig. 23. Smear from caeca of the cactus joint bug, Chelinidea tabulata (Burm.), showing bacterial symbiotes. Gram stained. Magnification approximately $1000 \times$.

The bacterial symbiotes of both species are gram-negative small rods, occurring singly, in pairs, and in filaments (fig. 23). Diphtheroidal, banded or vacuolated forms are frequently seen, particularly in C. tabulata. The average dimensions of the rods are 1.0 by 1.5 to 3.5 microns. The filamentous forms usually range from 10 to 15 microns in length. In $C$. vittiger the rods appear to be slightly smaller than in C. tabulata, and the predominant form is a single rod although some pairs and short chains are seen occasionally. The bacteria were present in large numbers in the caeca of the females and usually in those of the males, although no bacteria were discerned in one of the $C$. tabulata males examined.

Inasmuch as most of the attempts by other workers to cultivate on artificial media the caecal bacteria of Hemiptera have been unsuccessful, it was with some surprise that we found the symbiotes from both C. tabulata and C. vittiger capable of growing on such ordinary bacteriological media as nutrient agar and glucose nutrient agar. Growth on these media was at first rather 
slow ( 2 or 3 days) and the colonies were very small, discrete, white, entire, and glistening. Upon subsequent transfer the growth was somewhat faster and more abundant.

No attempt was made to identify the bacteria with regard to those groups of gram-negative rods already well known taxonomically. It was determined that none of the cultures isolated from either of the insects fermented lactose. The reactions in glucose were erratic. The organisms appear to be nonmotile. Both strains of bacteria are apparently short lived on artificial media since all cultures died within a few weeks. This should cause no distress, however, for anyone desiring to work with these bacteria, since they may be readily reisolated in pure culture.

Symbiotes in Rbantus. Several specimens of an unidentified species of the predaceous diving beetle (Rhantus) were brought to the laboratory on November 7 and 12, 1945, by J. W. MacSwain. Examination of them revealed that they possessed bacteria-filled outpocketings in a modified, broadened, and somewhat wrinkled part of the intestine. A similar accession was received from H. P. Chandler on March 20, 1947. Some time previous to this last accession, on January 28, 1946, Chandler submitted to the laboratory two specimens of Rhantus consimilis Mots. These also proved to be symbiote-carrying. In fact, two morphologically different symbiotes were present in Giemsastained smears prepared from the symbiote-containing tissues of this insect. The more prominent symbiote is a dark-staining, straight rod somewhat pointed toward each end, and occurring singly and in pairs. Its approximate size range is 0.9 to 1.2 by 4.0 to 7.0 microns. The second symbiote stains more faintly with Giemsa's solution than does the first. It is a very sinuous form with an approximate size range of 0.8 to 1.0 by 6.0 to 9.0 microns. No attempt was made to grow these symbiotes on artificial media.

\section{SUMMARY}

This paper constitutes a general and summarized report on the diagnoses of 575 accessions of dead and diseased insects (except for the inclusion of 27 accessions of healthy insects examined for symbiotes) received at our laboratory between August 1, 1944 and December 31, 1950. When the Laboratory of Insect Pathology was organized as part of the University of California's Division of Biological Control, it was not anticipated that the diagnostic service required of it would be as great as it has turned out to be. Accordingly, the procedures used in making and reporting the diagnoses have been rather unorganized and informal. However, by publishing the present paper it is hoped that the significant findings of most of the accessions can be gleaned and that future reporting of diagnoses can thereby be made more uniform and complete. Since it is evident that this service will receive even greater demands, the diagnostic service has now been made a regular part of the laboratory's activities.

The results of the diagnoses made, according to the kind of causative microorganism or the cause of death, were grouped as follows percentagewise: fungous infections, 34 per cent ; bacterial infections, 20 per cent ; virus infections, 18 per cent; protozoan infections, 11 per cent; accessions only for the purpose of ascertaining the presence or absence of symbiotes, 6 per cent; nematode infections, 2 per cent; and deaths resulting from nonmicrobial 
causes, 2 per cent. No diagnoses were rendered in 7 per cent of the accession received.

Among the microorganisms observed in or isolated from the insects submitted for diagnosis were found several apparently new species of viruses, bacteria, fungi, protozoa, and symbiotes. Some of the more noteworthy of these observations have been the bases of more detailed reports published elsewhere. Others are reported here for the first time. Included in the present report are the principal results obtained while conducting small research projects originating with some of the accessions. In general the principal findings dealt with the observation of several new as well as several previously recognized virus infections, an attempt to grow insect viruses in embryonated hen's eggs, the reisolation and redetermination of the bacterium responsible for widespread epizootics among grasshoppers, a revaluation of the pathogenic effects of so-called Bacillus "C" for scale insects, new host and locality data for several important entomogenous fungi and protozoa, and new and important records regarding certain intracellular and caecal symbiotes of insects.

\section{ACKNOWLEDGMENTS}

Although the responsibility for the diagnoses herein reported is that of the writer, he wishes to acknowledge the cooperation received from various members of the laboratory staff in making many of the diagnoses. This includes: C. G. Thompson, K. M. Hughes, Harriette B. Wasser, I. M. Hall, Catharine L. Boerke, K. D. Snyder, and Natalie Ross Herring who has assumed the clerical burdens connected with the accessioning of many of the insect specimens received. The photographs reproduced herein, as well as some of the microscopic preparations which they represent, were prepared for the author by K. M. Hughes, and in certain instances (figs. 9, 10, 15, 16, 18, and 22) by Hughes and J. M. Smith. 


\section{INDEX TO HOST INSECTS}

\section{(Listed according to species and genus)}

\section{A}

Acanthopsyche junodi, 647, 658-59

Acerophagus notativentris, 660 acraea, Estigmene, 634, 648

Alabama argillacea, 652

ambrosiae, Macrosiphum, 653

americanum, Malacosoma, 633

americanum, Neodiprion, 633

amygdalinus, Aphis, 655

amygdalinus, Brachycaudus, 655

ancylivorus, Macrocentrus, 638-39, 658

andersoni, Dermacentor, 637

angusticollis, Zootermopsis, 639

antiopa, Nymphalis, 639

Aonidiella aurantii, 645, 666

Aphis (Brachycaudus) amygdalinus, 655

Aphis frangulae, 655

Aphomia gularis, 644

Apis mellifera, 637, 659

areolata, Platypedia, 648

argillacea, Alabama, 652

Argyrotaenia velutinana, 634

Aspidiotus camelliae, 666

aurantii, Aonidiella, 645, 666

aurora, Okanagana, 648

Autographa californica, 643

\section{B}

bacoti, Bdellonyssus, 651

Bdellonyssus, bacoti, 651

beckii, Lepidosaphes, 648

Besorus sp., 651

bituberculata, Diadasia, 653

bivittatus, Melanoplus, 641-42

Brachycaudus amygdalinus, 655

brillians, Harrisina, 646

Brontispa mariana, 652

\section{C}

caberata, Sabulodes, 634, 652

californica, Autographa, 643

californica, Chrysopa, 658

californica, Nothochrysa, 659

californica, Phryganidia, 631

camelliae, Aspidiotus, 666

Camponotus sp., 649

Capitophorus fragaefolii, 648

cardui, Vanessa, 634

Carpocapsa pomonella, 651, 658

cautella, Ephestia, 659

cavus, Dibrachys, 639

Ceuthophilus sp., 648

Chelinidea tabulata, 670-71
Chelinidea vittiger, 670-71

Chrysolina hyperici, 651

Chrysopa californica, 658

Chrysopa majuscula, 658

Chlorochroa sayi, 670

Cirphis unipuncta, 631, 637, 643

Citri, Pseudococcus, 664

clarioralis, Dioryctria, 652

coelamboides, Hydroporus, 651

coenia, Junonia, 634

Colaspis pini, 652

Colias philodice eurytheme, 630, 643, 657

Coloradia pandora, 634

consimilis, Rhantus, 672

consociata, Diadasia, 653

constricta, Malacosoma, 643

convivus, Euryophthalmus, 643

corni, Lecanium, 665

cribrella, Myelois, 652

Culex pipiens, 655, 659

Culex tarsalis, 659

cucurbitae, Dacus, 655

cyanea, Gastroidea, 643

D

Dacus cucurbitae, 655

Dacus dorsalis, 639

dawsoni, Melanoplus, 642

Dermacentor andersoni, 637

Diadasia bituberculata, 653

Diadasia consociata, 653

Dibrachys cavus, 639

differentialis, Melanoplus, 639-41

Dioryctria clarioralis, 652

disstria, Malacosoma, 633

domestica, Musca, 639, 648

dorsalis, Dacus, 639

Draeculacephala minerva, 648

\section{E}

elutella, Ephestia, 659

Ephestia cautella, 659

Ephestia elutella, 659

Ephestia kühniella, 644, 646, 655

Estigmene acraea, 634, 648

Euryophthalmus convivus, 643

eurytheme, Colias philodice, 630, 643, 657

Euxoa segetum, 635

exigua, Laphygma, 633, 643

\section{F}

fasciculata, Oncopera, 658

fiscellaria lugubrosa, Lambdina, 630

fragaefolii, Capitophorus, 648 
fragilis, Malacosoma, 633

frangulae, Aphis, 655

\section{G}

gahani, Pseudococcus, 664

Gastroidea cyanea, 643

Gnorimoschema operculella, $638,643,655$, 658,660

gossypii, Phenacoccus, 664

Grapholitha molesta, 638

gularis, Aphomia, 644

\section{$\mathbf{H}$}

Harrisina brillians, 646

Hemerobius sp., 643

Hemerocampa pseudotsugata, 631

hirtipes, Prosimulium, 658

hirticollis vandykei, Pleocoma, 642-43

histrionica, Murgantia, 666

Hydroporus coelamboides, 651

Hypera postica, 643

Hypera punctata, 648

hyperici, Chrysolina, 651

\section{I}

interpunctella, Plodia, $643-4,655$

\section{J}

junodi, Acanthopsyche, 647, 658-59

Junonia coenia, 634

\section{K}

kühniella, Ephestia, 644, 646, 655

\section{L}

Lachnus persicae, 655

Lambdina fiscellaria lugubrosa, 630

Laphygma exigua, 633, 643

lascivum, Eusimulium, 658

lascivum, Simulium, 658

Lecanium corni, 665

Lecanium pruinosum, 665

lecontei, Neodiprion, 633

Lepidosaphes beckii, 648

Lepidosaphes newsteadi, 648

Lepidosaphes ulmi, 666

Leucania unipuncta, 631, 637

longispina, Stenopelmatus, 655

longispinus, Pseudococcus, 664

lugubrosa, Lambdina fiscellaria

\section{$\mathbf{M}$}

Macrocentrus ancylivorus, 638-39, 658

Macrosiphum ambrosiae, 653

Macrosiphum solanifolii, 648

Magicicada septendecim, 648

majuscula, Chrysopa, 658

Malacosoma americanum, 633

Malacosoma constricta, 643
Malacosoma disstria, 633

Malacosoma fragilis, 633

Malacosoma pluviale, 633,643

margaritosa, Peridroma, 634, 643

mariana, Brontispa, 652

maritimus, Pseudococcus, 660, 663

melanderi, Nomia, 652

Melanoplus sp., 648

Melanoplus bivittatus, 641-42

Melanoplus dawsoni, 642

Melanoplus differentialis, 639-41

Melanoplus mexicanus, 642

mellifera, Apis, 637, 659

Melolontha sp., 646,652

mexicanus, Melanoplus, 642

minerva, Draeculacephala, 648

molesta, Grapholitha, 638

molitor, Tenebrio, 643

Murgantia histrionica, 666

Musca domestica, 639, 648

Myelois cribrella, 652

Myelois venipars, 646

\section{$\mathbf{N}$}

Neodiprion americanum, 633

Neodiprion lecontei, 633 newsteadi, Lepidosaphes, 648 nigra, Saissetia, 664, 666

Nomia melanderi, 652

Nothochrysa californica, 659 notativentris, Acerophagus, 660

nubilalis, Pyrausta, 643, 651, 658-59

Nymphalis antiopa, 639

Okanagana aurora, 648

oleae, Parlatoria, 666

Oncopera fasciculata, 658

operculella, Gnorimoschema, 638, 653, 655, 658,660

\section{$\mathbf{P}$}

pandora, Coloradia, 634

Paracymus sp., 651

Parlatoria oleae, 666

Peridroma margaritosa, 634, 643

persicae, Lachnus, 655

persicae, Pterochlorus, 655

Phenacoccus gossypii, 664

philodice eurytheme, Colias, 630, 643, 657

Phlyctaenia rubigalis, 643

Phryganidia californica, 631

Pieris rapae, 634

pini, Colaspis, 652

pipiens, Culex, 655, 659

Plathypena scabra, 652

Platypedia areolata, 648

Pleocoma hirticollis vandykei, 642-43

Plodia interpunctella, 643-4, 655 
pluviale, Malacosoma, 633, 643 pomonella, Carpocapsa, 651, 658 postica, Hypera, 643 praefica, Prodenia, 631, 643 Prodenia praefica, 631, 643 Prosimulium hirtipes, 658 Protoparce sexta, 643 pruinosum, Lecanium, 665 Pseudococcus citri, 664 Pseudococcus gahani, 664 Pseudococcus longispinus, 664 Pseudococcus maritimus, 660, 663 pseudotsugata, Hemerocampa, 631 Pterochlorus persicae, 655 Pterochlorus viminalis, 653 punctata, Hypera, 648 Pyrausta nubilalis, 643, 651, 658-59

\section{$\mathbf{R}$}

rapae, Pieris, 634

Reticulitermes virginicus, 652

Rhantus sp., 672

Rhantus consimilis, 672 rubigalis, Phlyctaenia, 643

\section{$\mathrm{S}$}

Sabulodes caberata, 634, 652 Saissetia nigra, 664, 666 sayi, Chlorochroa, 670 scabra, Plathypena, 652 Sceliphron servillei, 652 Schistocerca shoshone, 640-41 Sciara sp., 648 segetum, Euxoa, 635 septendecim, Magicicada, 648

servillei, Sceliphron, 652

sexta, Protoparce, 643 shoshone, Schistocerca, 640-41

Simulium (Eusimulium) lascivum, 658

Simulium venustum, 658

Simulium vittatum, 658

solanifolii, Macrosiphum, 648

stanfordi, Tetraleurodes, 664

Stenopelmatus longispina, 655

\section{$\mathbf{T}$}

tabulata, Chelinidea, 670-71

tarsalis, Culex, 659

Tenebrio molitor, 643

Tetraleurodes stanfordi, 664

\section{$\mathbf{U}$}

ulmi, Lepidosaphes, 666

unipuncta, Cirphis [=Leucania], 631, 637, 643

vandykei, Pleocoma hirticollis, 642-43

\section{V}

Vanessa cardui, 634

velutinana, Argyrotaenia, 634

venipars, Myelois, 646

venustum, Simulium, 658

viminalis, Pterochlorus, 653

virginicus, Reticulitermes, 652

vittatum, Simulium, 658

vittiger, Chelinidea, 670-71

\section{$\mathbf{Z}$}

Zootermopsis angusticollis, 639 


\section{LITERATURE CITED}

Bergold, G. H., and B. M. McGugan.

1951. Virus diseases of the forest tent caterpillar. Canada Dept. Agr. Sci. Serv. Div. Forest Biol., Bimo. Prog. Rept. 7(1) :2-3.

BERLINER, E.

1915. Uber die Schlaffsucht der Mehlmottenraupe (Ephestia kühniella Zell.) und ihren Erreger Bacillus thuringiensis, n. sp. Ztschr. f. Angew. Ent. 2:29-56.

BlanCHARD, R. A., and C. B. CoNGer.

1932. Notes on Prodenia praefica Grote. Jour. Econ. Ent. 25:1059-70.

BUCHNER, P.

1930. Tier und Pflanze in Symbiose. 900 p. Gebrüder Borntraeger. Berlin.

1939. Symbiose der Tiere mit pflanzlichen Mikroorganismen. 123 p. Walter de Grunter \& Co., Berlin.

BURNSIDE, C. E.

1945. The cause of paralysis of honeybees. Amer. Bee Jour. 85:354-55; 363.

Chapman, J. W., and R. W. Glaser.

1915. A preliminary list of insects which have wilt, with a comparative study of their polyhedra. Jour. Econ. Ent. 8:140-50.

Dean, G. A., and R. C. SMith.

1935. Insects injurious to alfalfa in Kansas. Kans. State Bd. Agr. Bien. Rpt. 29:202-49.

Essig, E. O.

1926. Insects of Western North America. 1035 p. The Macmillan Co., New York.

Evenden, J. and E. J. Jost.

1947. A report of the tussock moth control, North Idaho, 1947. 51 p. Sponsored by Potlatch Timber Protective Assoc., Idaho State Forestry Dept., U. S. Dept. Agr., Forest Serv., Bur. Ent. and Plant Quar.

GLASER, R. W.

1930. The intracellular "symbionts" and the "rickettsiae." Arch. Path. 9:71-96; 557-76.

Glaser, R. W., and J. W. ChapMan.

1913. The wilt disease of gypsy moth eaterpillars. Jour. Econ. Ent. 6:479-88.

GLASGOW, H.

1914. The gastric caeca and the caecal bacteria of the Heteroptera. Biol. Bul. 26 : 101-70.

HETRICK, L. A.

1941. Life history studies of Neodiprion americanum (Leach). Jour. Econ. Ent. 34: $373-77$.

How ARD, L. O., and W. F. Fiske.

1911. The importation into the United States of the parasites of the gypsy moth and brown-tailed moth. U. S. Dept. Agr., Bur. Ent. Bul. 91:1-108.

MaINs, E. B.

1948. Entomogenous fungi. Mycologia 40:402-16.

Michelbacher, A. E., W. W. Middlekauff, and C. A. Hanson.

1951. Occurrence of a fungus disease in overwintering stages of the codling moth. Jour. Econ. Ent. $43: 955-56$.

Paillot, A.

1933. L'infection chez les insects. 535 p. G. Patissier, Trévoux.

1934. Un nouveau type de maladie à ultravirus chez les insectes. Acad. des Sci., Compt. Rend. [Paris] 198:204-05.

REEKs, W. A.

1946. The forest tent caterpillar (Malacosoma disstria Hbn.). Bi-Monthly Prog. Rpt., Forest Insect Invest., Canada Dept. Agr. 2:1.

Schoene, W. J., and N. V. Sibold.

1951. A virus disease of the red-banded leaf roller. Va. Fruit $39: 21-22$. 
SiboLd, N. V.

1950. Granulosis of the red-banded leaf roller. Virginia Jour. Sci. 1:266.

SoKoloff, V. P., and L. J. KLоTz.

1941. A bacterial pathogen of the citrus red scale. Science $94: 40-41$.

1942. Mortality of red scale on citrus through infection with a spore-forming bacterium. Phytopathology 32:187-98.

SPENCER, G. J.

1945. On the incidence, density and decline of certain insects in British Columbia. Ent. Soe. Brit. Columbia, Proc. 42:19-23.

Steinhaus, E. A.

1945a. Insect pathology and biological control. Jour. Econ. Ent. 38:591-96.

1945b. Bacterial infections of potato tuber moth larvae in an insectary. Jour. Econ. Ent. $38: 718-19$.

1946. Insect microbiology. 763 p. Comstock Publ. Co., Inc., Ithaca, N.Y.

1947a. A coccidian parasite of Ephestia kühniella Zeller and Plodia interpunctella (Hbn.) (Lepidoptera, Phyatidae). Jour. Parasitol. 33:29-32.

1947b. A new disease of the variegated cutworm, Peridroma margaritosa (Haw.). Science $106: 323$.

1948. Polyhedrosis ("wilt disease") of the alfalfa caterpillar. Jour. Econ. Ent. 41: 859-65.

1949a. Principles of insect pathology. 757 p. McGraw-Hill Book Co., New York.

1949b. Nomenclature and classification of insect viruses. Bact. Revs. 13:203-23.

1950. Diagnoses of insect diseases; microbial infections in insects diagnosed as part of the research in developing new ways of controlling erop pests. Calif. Agr. 11:11, 15.

1951. Possible use of Bacillus thuringiensis Berliner as an aid in the biological control of the alfalfa caterpillar. Hilgardia $20: 359-81$.

STEinhaus, E. A., and K. M. Hughes.

1949. Two newly described species of Microsporidia from the potato tuberworm, Gnorimoschema operculella (Zeller) (Lepidoptera, Gelechiidae). Jour. Parasitol. 35: $67-75$.

Steinhaus, E. A., K. M. Hughes, and H. B. Wasser.

1949. Demonstration of the granulosis virus of the variegated cutworm. Jour. Bact. 57: $219-24$.

Steinhaus, E. A., and C. G. Thompson.

1949a. Preliminary field tests using a polyhedrosis virus to control the alfalfa caterpillar. Jour. Econ. Ent. 42:301-05.

1949b. Granulosis disease in the buckeye caterpillar, Junonia coenia Hübner. Science $110: 276-78$.

Thompson, C. G., and E. A. Steinhaus.

1950. Further tests using a polyhedrosis virus to control the alfalfa caterpillar. Hilgardia $19: 411-45$.

Wasser, H. B., and E. A. Steinhaus.

1951. Isolation of a virus causing granulosis of the red-banded leaf roller. Virginia Jour. Sci. 2:91-93. 
The journal Hilgardia is published at irregular intervals, in volumes of about 600 pages. The number of issues per volume varies.

Subscriptions are not sold. The periodical is sent as published only to libraries, or to institutions in foreign countries having publications to offer in exchange.

You may obtain a single copy of any issue free, as long as the supply lasts; please request by volume and issue number from:

Publications Office

College of Agriculture

Berkeley 4, California

The limit to nonresidents of California is 10 separate issues on a single order. A list of the issues still available will be sent on request. 


\section{CONTENTS}

Report on Diagnoses of Diseased Insects 1944-1950, by

Edward A. Steinhaus . . . . . . . . . . . . . . . . . . . . 629

Introduction ................................629

Virus Infections . . . . . . . . . . . . . . . . . . . 630

Polyhedroses .............................630

Granuloses ..............................634

Cultivation Attempts ...................... 635

Noninclusion Virus Infections. . . . . . . . . . . . . . . 637

Bacterial Infections . . . . . . . . . . . . . . . . . . 638

Enterobacteriaceae Infections . . . . . . . . . . . . . . 638

Bacillaceae Infections . . . . . . . . . . . . . . . . . . 643

Fungous Infections. . . . . . . . . . . . . . . . . . 647

Phycomycete Infections . . . . . . . . . . . . . . . . 647

Ascomycete Infections . . . . . . . . . . . . . . . . . 648

Fungi Imperfecti Infections $\ldots \ldots \ldots \ldots \ldots \ldots \ldots \ldots \ldots \ldots \ldots \ldots$

Protozoan Infections . . . . . . . . . . . . . . . . . . 655

Symbiotes in Healthy Insects. .................... 660

Intracellular symbiotes....................... 660

Caecal symbiotes . . . . . . . . . . . . . . . . . . . . . 666

Summary $\ldots \ldots \ldots \ldots \ldots \ldots \ldots \ldots \ldots \ldots \ldots \ldots \ldots \ldots \ldots \ldots \ldots \ldots 72$

Acknowledgments $\ldots \ldots \ldots \ldots \ldots \ldots \ldots \ldots \ldots \ldots \ldots \ldots \ldots \ldots \ldots$

Index to Host Insects. . . . . . . . . . . . . . . . . . . . 674

Liferature Cited $\ldots \ldots \ldots \ldots \ldots \ldots \ldots \ldots \ldots \ldots \ldots \ldots \ldots \ldots \ldots \ldots 6$ 